\title{
EVOLUTIONARY HISTORY OF NORTHERN HEMISPHERE NUCELLA (GASTROPODA, MURICIDAE): MOLECULAR, MORPHOLOGICAL, ECOLOGICAL, AND PALEONTOLOGICAL EVIDENCE
}

\author{
Timothy M. Collins, ${ }^{1,2}$ Kenneth Frazer, ${ }^{1,3}$ A. Richard Palmer, ${ }^{4}$ \\ GeERAt J. VermeiJ, ${ }^{5}$ AND WeSLey M. BROWN ${ }^{1,6}$ \\ ${ }^{1}$ Department of Biology, University of Michigan, Ann Arbor, Michigan 48109-1048 \\ ${ }^{6}$ E-mail: WBrown@Biology.LSA.UMich.edu \\ ${ }^{4}$ Department of Zoology, University of Alberta, Edmonton, Alberta T6G 2E9, Canada \\ and Bamfield Marine Station, British Columbia VOR IBO, Canada \\ E-mail: Rich.Palmer@UAlberta.CA \\ ${ }^{5}$ Department of Geology, University of California, Davis, California 95616 \\ E-mail: GJVermeij@UCDavis.edu
}

\begin{abstract}
By combining data from a variety of sources we explore patterns of evolution and speciation in Nucella, a widely studied genus of shallow-water marine neogastropods. We present a hypothesis of phylogenetic relationships for all of the currently recognized species of northern hemisphere Nucella, based on an analysis of 718 base pairs of nucleotide sequence from the mitochondrial cytochrome $b$ gene. The order of appearance of species in the fossil record is congruent with this hypothesis. The topology of the inferred phylogeny of Nucella, coupled with ecological, morphological, and fossil evidence, was used to address three main questions: (1) At what time and by which route was the North Atlantic invaded from the North Pacific compared to prior studies of the trans-Arctic interchange? (2) Do patterns of molecular variation within species corroborate the importance of climatic cycles in driving speciation in north temperate marine animals? (3) Was radiation in the direction of increased or decreased ecological specialization, body size, or vulnerability to predation?

Molecular evidence confirmed that the sole North Atlantic species, $N$. lapillus, arose from a North Pacific ancestor. Biogeographic and paleontological evidence supported the dispersal of Nucella, and perhaps other interchange species, via the Eurasian Arctic. Rather intriguingly, the linkage of $N$. lapillus to a western as opposed to eastern Pacific clade, and the biogeographic origins of the eastern Pacific species, parallel closely similar patterns observed in another genus of rocky-shore gastropods, Littorina. This congruence, in conjunction with information on the climatic and geographic histories of the region, as well as the geographic arrangement of mtDNA haplotypes within Nucella species, supports a model of speciation in Nucella driven by cycles of climatic amelioration and deterioration that began during the Miocene. Calibrations from the fossil record of Nucella suggest that third position transitions and transversions accrue at a rate of $3-4 \%$ and $0.5 \%$ respectively per million yr. This supports an early participation by Nucella in the transArctic interchange, as suggested by paleobiogeographic studies.

Consistent with the unstable taxonomic history of species of Nucella, we found few nonmolecular traits to be phylogenetically informative. Among North Pacific species, more recently derived species ( $N$. canaliculata and the $N$. emarginata clade) were more ecologically specialized (narrower diet and habitat range). Consistent with extensive intraspecific variation, shell traits were quite labile evolutionarily: neither overall size nor development of antipredatory traits exhibited consistent evolutionary trends over the history of the genus. Nurse eggs (unfertilized eggs consumed by developing embryos) were an ancestral trait that was lost evolutionarily in the two clades that also exhibited increased body size, suggesting that these two life-history traits may be coupled. The reduced number of chromosomes in $N$. lapillus is clearly a derived state and is consistent with White's (1978) observations on chromosome evolution in other clades.
\end{abstract}

Key words.-Bering Strait, biogeography, character evolution, climate, cytochrome $b$, invasion, mtDNA, phylogeography, rate of molecular evolution, speciation, vicariance.

Received February 15, 1995. Accepted June 20, 1996.

Species in the neogastropod genus Nucella, the dog whelks, offer excellent opportunities to test hypotheses about geographical, ecological, and temporal aspects of speciation. This genus comprises six living North Pacific and one North Atlantic species of abundant predatory snails whose ecology, genetics, shell variation, reproductive biology, and behavior have been extensively studied on rocky shores (Crothers 1985; Hughes 1986; Strathmann 1987; Palmer 1990 and references therein). Its fossil record, spanning an interval of

\footnotetext{
2 Present address: Department of Biological Sciences, Florida International University, University Park, Miami, Florida 33199; E-mail: CollinsT@FIU.edu.

${ }^{3}$ Present address: Jackson Laboratory, 600 Main Street, Bar Harbor, Maine 04609; E-mail: KSF@informatics.jax.org.
}

about 25 million yr from the Early Miocene to the Recent, includes all the living species as well as several extinct forms. We add to this a hypothesis of relationships for Nucella, based on a comparison of 718 base pairs (bp) of nucleotide sequence from the mitochondrial cytochrome $b$ gene.

The strength of a multidisciplinary approach to speciation lies both in the more complete picture of the evolutionary milieu, and in the increased confidence in inferences supported by independent data sets. A phylogenetic hypothesis, in this case generated from sequence data, is necessary for the analysis of patterns of species distribution, speciation, the evolution of morphological and ecological characters, and adaptation (Maddison and Maddison 1992). In addition, for the first time, we characterize patterns of molecular variation 
in the mitochondrial cytochrome $b$ gene of numerous marine gastropod species.

Several authors (e.g., Golikov and Tzvetkova 1972; Reid $1990 \mathrm{a}, \mathrm{b})$ have suggested that fluctuations in climate leading to shifts in geographical limits during the Late Cenozoic have provided conditions favorable for genetic isolation and subsequent speciation in temperate marine organisms. Nucella, along with hundreds of other marine animals and plants, probably invaded the Atlantic Ocean from the North Pacific through the Bering Strait after the latter seaway opened during the Early Pliocene (see Vermeij 1991 and references therein). This inference was based on fossil occurrences and on qualitative similarities between the shells of the North Atlantic $N$. lapillus and several Pacific species. We map the distributions of living species onto a molecular phylogeny to illuminate the biogeographic history of the genus in the North Pacific, to test the hypothesis that Nucella participated in the so-called trans-Arctic interchange, and to corroborate the direction and timing of the interchange inferred from the fossil record. Molecular data are also used to discover patterns of geographic variation within Nucella species, which are then related to processes thought to be driving differentiation in Nucella and similarly distributed taxa.

Calibration of molecular rates with the fossil record, or other biogeographic events, gives a rough time scale to both within and between species processes in Nucella, and allows checks of their correspondence, on an absolute time scale, to independently dated climatic or biogeographic events. The fossil record, in combination with the phylogeny, yields minimum divergence times for cladogenetic events, gives some insights into the temporal and geographic origin of species, and presents us with information about the numbers of extinct species and their characters.

These independent data sets result in inferences that may be supported or contradicted by inferences from the other data sets. Inferences supported by several independent data sets may be considered highly corroborated, and are likely to reflect the true evolutionary history of a clade. For example, the study of character state transformations can reveal the likely history of a character of interest. The phylogenetic hypothesis presented here makes predictions about the probable direction of character state transformations and combinations of characters in basal versus derived species. We test these predictions by examination of the characters and temporal distributions of fossil species. The phylogeny of living Nucella species also makes predictions about the order of stratigraphic appearance of taxa, which we compare to the known fossil record. Time scales derived from the combination of fossil and molecular data can be compared to independently derived calibrations from other events, in this case the Pliocene emergence of the Isthmus of Panama, as an independent check on both.

\section{Materials And Methods}

\section{Taxonomy of Nucella}

The genus Nucella as used here in the restricted sense contains Miocene to Recent species from the North Pacific and North Atlantic Oceans. On the basis of anatomical studies and a phylogenetic analysis of muricid groups, Kool (1993a,b) has shown that Nucella is a member of the muricid subfamily Ocenebrinae and is therefore subfamilially distinct from the rapanine genus Thais, in which Nucella was included by many previous authors. South African species referred to Nucella (Kilburn and Rippey 1982) differ from northern species in characters of the egg capsule and shell, and have been excluded from Nucella (Vermeij 1993a). The relationship between the South African taxa formerly referred to as Nucella and Northern Hemisphere Nucella will be the subject of a later paper. Several authors have considered the taxa Acanthina and Acanthinucella from the Pacific coasts of North and South America as subgenera of Nucella. Nucella may share a common ancestor with Acanthina and Acanthinucella, but there is no evidence at present that the latter two genera are derived from any member of Nucella (Amano et al. 1993; Vermeij 1993a).

Most species of Nucella are well defined, and can be recognized based on apertural shape and the number and pattern of spiral cords on the penultimate and body whorls. However, we and others (Dall 1915) had difficulty confirming the identity of western Pacific species. Russian authors (Golikov and Kussakin 1978; Egorov 1992) generally recognize four species: $N$. lima (Gmelin 1791), N. freycineti (Deshayes 1841), $N$. heyseana (Dunker 1882), and N. elongata (Golikov and Kussakin 1962). In southern Hokkaidô, where N. lima does not occur, Habe (1958) recognized only two species, $N$. freycineti and what he called $N$. lamellosa (Gmelin 1791). This latter taxon was subsequently named $N$. elongata by Golikov and Kussakin (1962). Identified shells sent by A. N. Golikov to GJV and ARP overlap so much in form and sculpture that we are unable to associate diagnostic shell traits with specific names. In view of the extensive intraspecific variation known to occur in species of Nucella and the overzealous naming of shell variants by early malacologists (reviewed in Palmer et al. 1990), we have opted to pool information for these three nominal species under the name that has taxonomic priority, $N$. freycineti.

The status of Nucella emarginata (Deshayes 1839) also remains unsettled. Palmer et al. (1990) showed that this name applies to two species, a southern form from California and Baja California and a northern form ranging from southeastern Alaska to California. Deshayes's syntypes are clearly of the "southern" species (ARP pers. obs.), but the identity of the "northern" species remains in doubt. We thus adhere to the recommendations of Palmer et al. (1990) and refer to these as the "northern" and "southern" species of N. emarginata. Recent collections by one of us (GJV) suggests the possibility that a southern variant of $N$. canaliculata exists, paralleling the pattern found in $N$. emarginata. This form, referred to by Dall (1915) as Thais (Nucella) canaliculata var. compressa, exhibits some unique morphological characteristics, and could represent a distinct species most closely related to typical $N$. canaliculata, but more study will be required to test this hypothesis.

To ensure consistent identification of samples used for molecular analysis, voucher specimens for all but $N$. lapillus were inspected by ARP. Finally, we examined specimens (usually including type material) of nearly all fossil species of Nucella. Difficulties in the interpretation of fossil taxa are dealt with in the Fossil Record section of the Results. 


\section{DNA Sequences}

All species were sampled over a significant portion of their geographic ranges (from approximately $250 \mathrm{~km}$ for $N$. freycineti to over $3000 \mathrm{~km}$ of coastline for $N$. lima), except for $N$. emarginata-S, which was sampled from a single locality (Table 1; Fig. 1). DNA samples were prepared from individual animals by extraction of total DNA from fresh, frozen, or $70 \%$ ethanol-preserved tissues following a slight modification of the protocol of Doyle (1990). Heart tissue samples (approximately $0.01-0.10 \mathrm{~g}$ ) were homogenized in disposable microfuge tissue grinders (Kontes Scientific Instruments cat 749520) with $700 \mu \mathrm{L} 2 \times$ CTAB buffer, after which $5 \mu \mathrm{L}$ aliquots of $20 \mathrm{mg} / \mathrm{ml}$ Proteinase $K$ were added and the samples incubated at $65^{\circ} \mathrm{C}$ for $1 \mathrm{~h}$. Samples were then extracted with phenol:chloroform:isoamyl alcohol (25:24:1), followed by a chloroform:isoamyl alcohol (24:1) extraction and precipitation with 1 volume of isopropanol at $-20^{\circ} \mathrm{C}$ overnight. DNAs were pelleted in a microfuge, resuspended in $100 \mu \mathrm{L}$ TE (10 mM Tris pH 8.3,1 mM EDTA), brought to a final concentration of $2.5 \mathrm{M}$ ammonium acetate and reprecipitated by adding 2.5 volumes of ice-cold ethanol. After a second pelleting in a microfuge, samples were air dried and resuspended in 1/10 TE. Amplifications were performed in 100 $\mu \mathrm{L}$ volume of a solution containing $10 \mathrm{mM}$ Tris $(\mathrm{pH} 8.3$ ), $50 \mathrm{mM} \mathrm{KCl}, 1.5 \mathrm{mM} \mathrm{MgCl}_{2}, 0.01 \%$ gelatin (Difco), each primer at $0.5 \mu \mathrm{M}$, each dNTP at $200 \mu \mathrm{M}, 10-1000 \mathrm{ng}$ template DNA, and 2 units of Taq Polymerase (Perkin-Elmer/ Cetus). The primers used were designed by alignment of the complete cytochrome b sequences of the neogastropod, Plicopurpura columellaris (Collins and Brown unpubl. data), a chiton, Katharina tunicata (Boore and Brown 1994), a fly, Drosophila yakuba (Clary and Wolstenholme 1985), and two urchins, Strongylocentrotus purpuratus (Jacobs et al. 1988) and Paracentrotus lividus (Cantatore et al. 1989). Primers were chosen from regions of high sequence conservation among these taxa, with any differences being resolved in favor of the gastropod sequence. A HindIII site and three additional $\mathrm{A}$ nucleotides were added to the $5^{\prime}$ end of each primer to facilitate cloning. The primer sequences and the position of the $3^{\prime}$ end of the primer in the human mitochondrial sequence (Anderson et al. 1981) are, for primer 1: $5^{\prime}$ AAAAAGCTTCCTTCTAATCTCTCAGTTTGATGAAA- ${ }^{\prime}$ (14,841), primer 2: 5'-AAAAAGCTTAATTGATCGAAGAATAGCATAGGCAA- $3^{\prime}(15,573)$. These primers amplify a 731 base pair portion of the cytochrome $b$ gene in $P$. columellaris.

PCR protocols are a slight modification of Kreitman et al. (1989). The PCR cycling parameters for double stranded amplification were $30 \mathrm{sec}$ to $1 \mathrm{~min}$ at $94^{\circ} \mathrm{C}, 45 \mathrm{sec}$ to $1.5 \mathrm{~min}$ at $55^{\circ} \mathrm{C}$, and 1.25 to $1.5 \mathrm{~min}$ at $72^{\circ} \mathrm{C}$, for 24 to 28 cycles. Amplified products were chloroform extracted, precipitated, resuspended in TE, electrophoresed on 2-3\% Nu-Sieve TAE agarose gels (FMC BioProducts), and stained with ethidium bromide. DNA bands were visualized under long wavelength (305 nm) UV, excised with glass cover slips, and purified with the GeneClean kit (Bio 101 company). One-quarter to one-third of the double-stranded product was then used in a second, single-stranded amplification identical to the first amplification except for the addition of a single primer and the following cycling parameters: $30 \mathrm{sec}$ to $1 \mathrm{~min}$ at $94^{\circ} \mathrm{C}, 45$ sec to $1.5 \mathrm{~min}$ at $65^{\circ} \mathrm{C}$ and 1 to $1.5 \mathrm{~min}$ at $72^{\circ} \mathrm{C}$, for 19 to 20 cycles. This single-stranded product was chloroform extracted, concentrated and purified with Ultrafree-MC UFC3 TTK 30,000 NMWL microconcentrators (Millipore). Sequencing was performed with Sequenase 2.0 (United States Biochemical) according to the manufacturer's suggestions and using the PCR primer that was not used in the singlestranded amplification. Internal sequencing primers were designed based on the sequence information from these first sequencing reactions.

\section{Phylogenetic Analyses}

The outgroup taxa used for all analyses were $P$. columellaris and Plicopurpura patula, two Neotropical representatives of the Rapaninae subfamily (sensu Kool 1993a,b) of the Muricidae that form a geminate pair in the western Atlantic and eastern Pacific (Vermeij 1978; Collins 1989). Within the Muricidae, the subfamily Rapaninae is the sister clade to the subfamily Ocenebrinae, which includes Nucella. The use of these taxa as outgroups has the additional advantage of allowing an independent temporal calibration based on the emergence of the Isthmus of Panama. Estimates of rates of sequence divergence were derived from comparisons of pairwise and patristic differences between taxa calibrated by fossil occurrences and biogeographic events. Calibration points are listed with fossil occurrences in the Appendix.

Parsimony analyses were performed with PAUP (Ver. 3.0q, Swofford 1990). Characters were designated as unordered when equally weighted, and multiple states within taxa for a given character were treated as polymorphisms. Phylogenetic analyses using parsimony were limited to potentially informative characters and were carried out on two differently compiled data sets. In the first data set, referred to as the INDIV data set, single individuals, representing all of the different haplotypes found in each of the currently recognized species, were analyzed in different combinations and in toto. In the second set, hereinafter referred to as the POLY data set, composite sequences for each of the currently recognized species were created, representing all of the polymorphisms found within the individuals sampled for that taxon. The only exception to this was $N$. lima, for which the magnitude and geographic patterning of molecular variation suggested the possibility that two distinct lineages were combined under one species name. These lineages were treated separately as the eastern (Kodiak and Sitka) and western (Shemya and Amchitka) forms of $N$. lima. These two types of data set were analyzed to evaluate the effect of intraspecific polymorphism on phylogenetic reconstruction among closely related species.

Transversions were weighted relative to transitions at three levels: 8:1 weighting (the value used unless otherwise specified), equal weighting, and transversions only. The rationale for these weighting schemes will be discussed below (see Molecular Evolution and the Phylogeny of Nucella). Weighting was achieved by appending a stepmatrix to the data file. The PAUP program does not provide basic statistics other than tree length for stepmatrix characters. Trees are based on exhaustive or branch and bound searches. A decay index 
TABLE 1. Geographic ranges and collection information for species of Nucella examined in this study.

\begin{tabular}{|c|c|c|c|}
\hline Taxon & Geographic range & Samples for DNA analyses§ & Collected by (year)* \\
\hline N. lima & N. Japan to N. Vancouver Is. ${ }^{1,2}$ & $\begin{array}{l}\text { Shemya Is. (1 C), Amchitka (1 C), Kodi- } \\
\text { ak Is. (1 B), and Sitka (1 A), AK }\end{array}$ & GJV \& ARP (1987) \\
\hline N. freycineti & $\begin{array}{l}\text { N. Honshû and Hokkaidô to Bering Sea; ab- } \\
\text { sent from Aleutians }{ }^{1,3}\end{array}$ & $\begin{array}{l}\text { Tsukuskikoi, E. Hokkaidô (4D, } 1 \text { E) } \\
\text { Usujiri, S. Hokkaidôa }(4 \text { F), Japan }\end{array}$ & $\begin{array}{l}\text { GJV (1988) } \\
\text { SG \& KK (1992) }\end{array}$ \\
\hline N. lamellosa & $\begin{array}{l}\text { Aleutian Is. to Santa Cruz, CA; }{ }^{1,4} \text { absent } \\
\text { from Kurile and Commander Is. }\end{array}$ & $\begin{array}{l}\text { Cattle Pt., San Juan Is., WA }{ }^{\mathbf{b}}(1 \mathrm{~J}, 1 \mathrm{~K}, 1 \\
\text { L) } \\
\text { Kodiak Is. (1J), Cordova ( } 2 \mathrm{~J}), \text { AK }\end{array}$ & $\begin{array}{l}\text { PBM (1991) } \\
\text { GJV \& ARP (1987) }\end{array}$ \\
\hline N. emarginata- $\mathrm{N}$ & Yakutat, AK to Pt. Conception, $\mathrm{CA}^{5.6}$ & $\begin{array}{l}\text { Queen Charlotte Is., BC, Canada (1 Q) } \\
\text { Torch Bay, } \mathrm{AK}^{\mathrm{c}}(1 \mathrm{Q})\end{array}$ & $\begin{array}{l}\text { ARP }(1985) \\
\text { ARP }(1982)\end{array}$ \\
\hline$N$. emarginata-S & Half Moon Bay, CA to Baja California ${ }^{5,6}$ & Monterey Harbor, CA (1 O, 2 P) & LW (1992) \\
\hline$N$. lapillus & $\begin{array}{l}\text { Sole Atlantic species; Novaya Zemlya to Por- } \\
\text { tugal in the east; } 7 \text { Greenland to Long Is- } \\
\text { land in the } \text { west }^{4}\end{array}$ & $\begin{array}{l}\text { Giant Steps, Bailey Is., ME (1 H, } 1 \text { I) } \\
\text { Norris Pt., Bonne Bay, Nfld., Canada (1 } \\
\text { G) }\end{array}$ & $\begin{array}{l}\text { NW (1992) } \\
\text { GJV (1990) }\end{array}$ \\
\hline
\end{tabular}

\& See Vermeij et al. 1990 for details of Aleutian Is. collecting sites; items in parentheses are the number of snails for which 718 bp of contiguous sequence were obtained and the letter of the haplotype(s) found (see Fig. 1 for map of localities; GenBank for haplotype designations).

* SG: S. Goshima; KK: Kei Kawai; PBM: Peter B. Marko; ARP: A. Richard Palmer; GJV: Geerat J. Vermeij; LW: Lani West; NW: Nathanial Wheelwright. Geographic range references: 1 Vermeij et al. (1990); ${ }^{2}$ A. R. Palmer (pers. obs.); ${ }^{3}$ G. J. Vermeij (pers. obs.); ${ }^{4}$ Abbott (1974); ${ }^{5}$ Palmer et al. (1990);

${ }^{6}$ P. B. Marko (pers. comm.); ${ }^{7}$ Cooke (1915)

Latitude and longitude: ${ }^{\mathrm{a}} 42^{\circ} 21^{\prime} \mathrm{N}, 140^{\circ} 57^{\prime} \mathrm{E}$; b $48^{\circ} 21^{\prime} \mathrm{N}, 122^{\circ} 58^{\prime} \mathrm{W} ;{ }^{\mathrm{c}} 58^{\circ} 19^{\prime} 41^{\prime \prime} \mathrm{N}, 136^{\circ} 47^{\prime} 56^{\prime \prime} \mathrm{W}$

(Bremer 1988; Donoghue et al. 1992) was calculated to indicate the relative support for clades found in the most parsimonious tree.

Maximum-likelihood distance trees were generated with PHYLIP version 3.4 (Felsenstein 1991). Distance matrices were constructed by the DNADIST81 program on the following settings: maximum-likelihood distance, equilibrium frequencies of the nucleotides assumed to be the observed frequencies in the input sequences, transition/transversion ratios of 1:1, 8:1, 100:1, and three categories of substitution rates for first, second, and third positions of codons in the ratios of $1: 1: 1$ and $6: 1: 44$. Ratios for categories were derived from empirical results. A tree was then constructed from the distance matrix with the FITCH81 program with the power

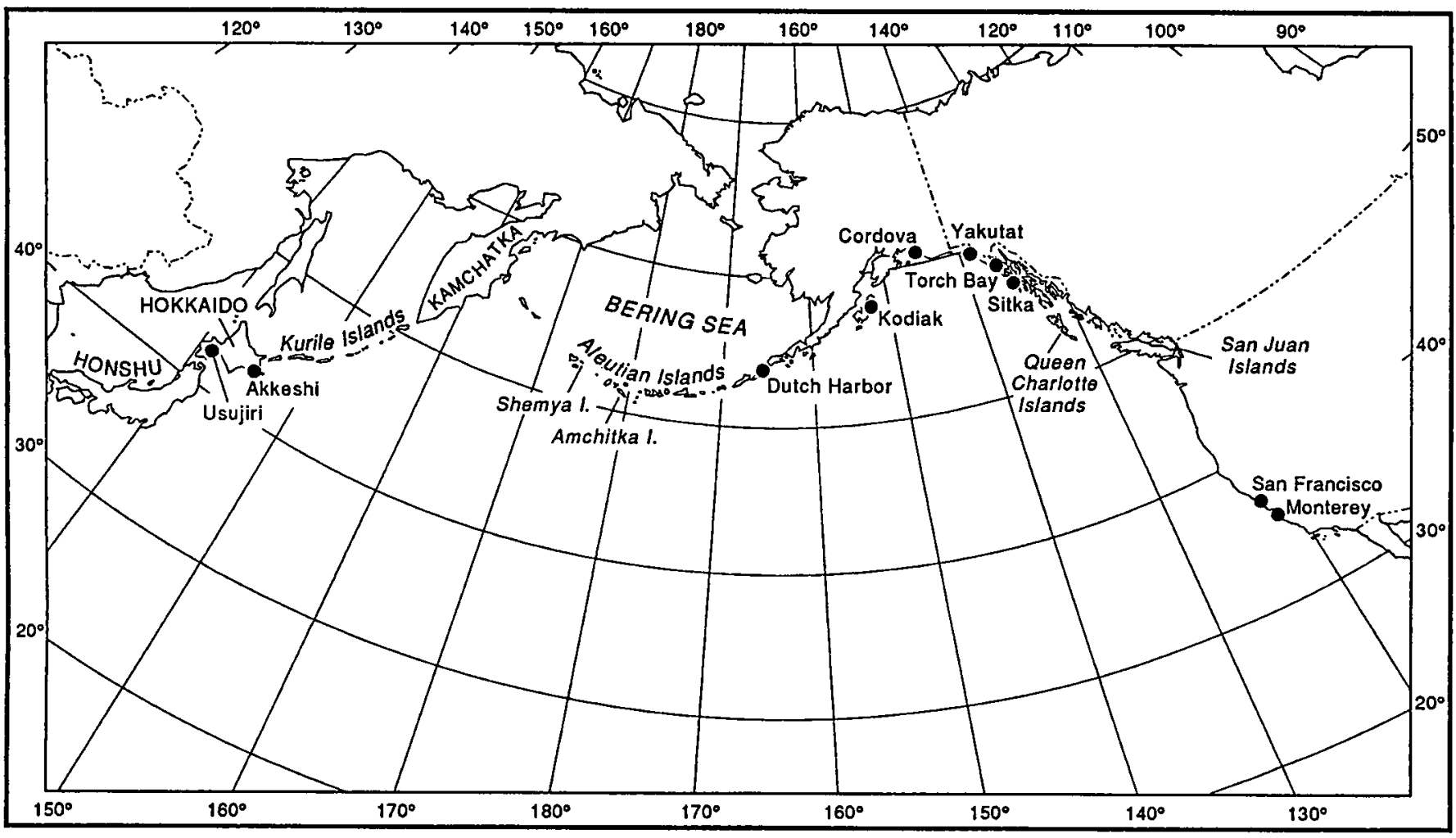

FIG. 1. North Pacific localities referred to in Table 1 and in text. 
TABLE 2. Ecological and morphological characteristics of Nucella species.

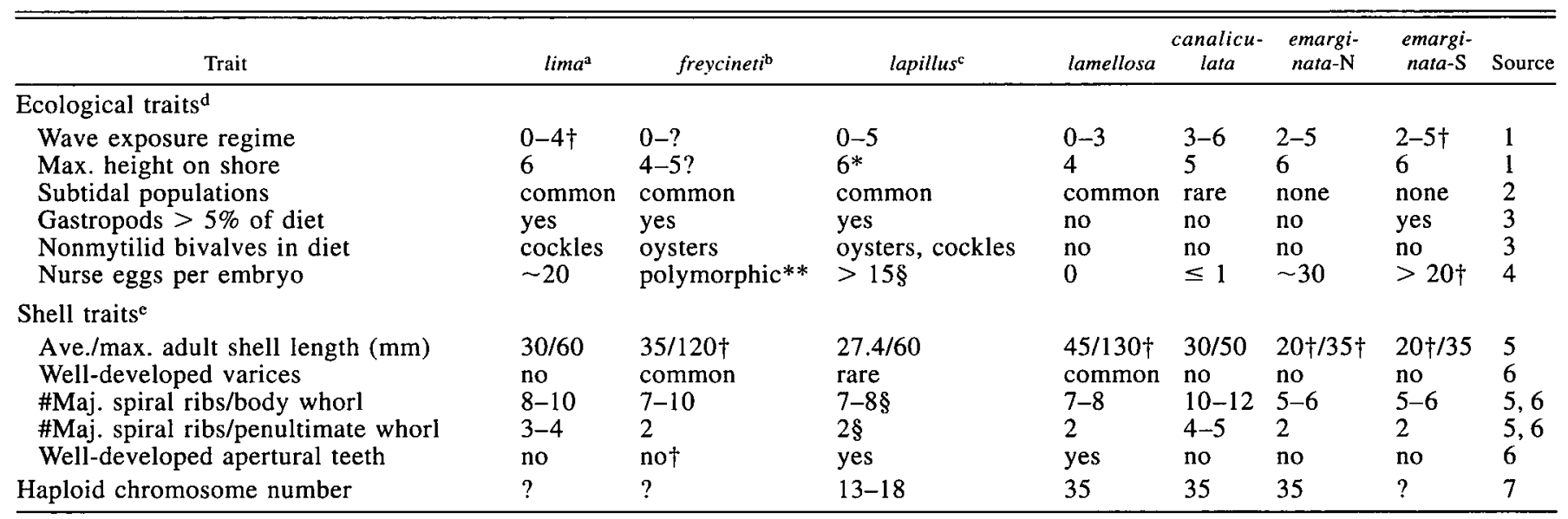

a The molecular data suggest $N$. lima may be composed of two cryptic species, hence characteristics reported here may be for either species.

${ }^{\mathrm{b}}$ All information on $N$. freycineti includes information pooled for $N$. freycineti, $N$. heyseana, and $N$. elongata (see Taxonomic Considerations section in methods) from Golikov and Kussakin (1978) except $\dagger$.

${ }^{c}$ All information on $N$. lapillus from Crothers (1985) except $\S$ and *.

d Details of ecological traits: wave exposure qualitative ranking: $0=$ protected bays to $6=$ most wave-exposed outer coast; max. height on shore: $0=$ extreme lower-low water spring tide to $6=20-30 \mathrm{~cm}$ from the top edge of the high-shore barnacle zone.

e Details of shell traits: shell length was measured from the apex to the tip of the siphonal canal. Only varices greater than 2 mm width were considered well developed. Major spiral ribs were scored by counting only the most pronounced ribs exhibited on the body whorl (between the tip of the siphonal canal and the first suture between whorls) and the penultimate whorl (between the first and second sutures adjacent to the apertural margin). Only apertural teeth $>0.1 \mathrm{~mm}$ high were considered well developed.

Sources: ${ }^{1}$ Palmer (1980); ${ }^{2}$ ARP (unpubl. obs.); ${ }^{3}$ West (1986), Palmer (1988); ${ }^{4}$ Spight (1976), Rivest (1981), Strathmann (1987); ${ }^{5}$ Dall (1915); 6 Abbott

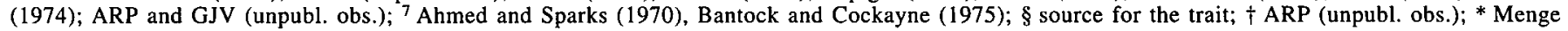
(1976); ** none (ARP unpubl. obs.)/many (Kawai 1993).

set to 2 (Fitch-Margoliash method), no negative branch lengths allowed, global rearrangements, and randomized entry of sequences.

\section{Ecological, Reproductive, and Morphological Attributes of Living Nucella}

Nearly all information on ecological and reproductive traits in Nucella was obtained from the literature. We report these values as precisely as possible, given the availability of published data. Information on most shell traits was compiled by ARP and GJV based upon shells in the Vermeij collection at the University of California, Davis. Details of traits, measurement protocols, and sources are in the footnotes to Table 2.

These data were used to analyze evolutionary trends and patterns of character evolution in Nucella, but were not used in the phylogenetic analyses. We excluded the morphological and ecological traits for two reasons. First, several traits are continuous and highly variable within, as well as between, species and we could not assign discrete character states with confidence. Second, some species (e.g., N. freycineti) are not nearly as well known as others (e.g., N. lapillus). Thus, while we feel that the coarse categorizations presented here are sufficient for outlining broad evolutionary patterns within Nucella, they are not yet refined or complete enough for all species to be included in the phylogenetic analysis or used in sensitivity tests (Maddison and Maddison 1992). At such time as these characters become more fully known, their inclusion in the phylogenetic analysis will be appropriate, although the potential problem of circularity or bias in the study of character evolution (Brooks and McLennan 1991; Maddison and Maddison 1992) needs to be considered.

\section{Results}

\section{Phylogenetic Analyses}

The following analyses are based on variation within 718 bp of contiguous cytochrome $b$ sequence, deposited in GenBank under the accession numbers U69710-U69728. Average nucleotide composition on the coding strand of Nucella species was $40 \% \mathrm{~T}, 25 \% \mathrm{~A}, 18 \% \mathrm{C}$, and $17 \% \mathrm{G}$. Individual species differed by less than $2 \%$ from these averages, indicating that marked shifts in overall nucleotide bias have not occurred among these taxa. Nucleotide bias was most pronounced at third positions of codons, $83 \%$ of which were either A or T (Table 3). Nucleotide composition varied most markedly among species at the third positions of codons, and in some cases deviated more than $5 \%$ from the average values of $49 \% \mathrm{~T}, 34 \% \mathrm{~A}, 11 \% \mathrm{C}$, and $6 \% \mathrm{G}$. Amino acid differences in this region of cytochrome $b$, as inferred using the "invertebrate" mitochondrial genetic code (MacVector Vers. 3.5, International Biotechnologies), were too few to be of use for phylogenetic studies within Nucella.

A total of 165 nucleotide sites (23\% of total sites) varied among the Nucella individuals sequenced. These differences were unequally distributed among the three codon positions, a pattern typical of mitochondrial protein-coding genes in other animals (Brown 1985). Variation at third positions, which are predominantly silent, accounted for $86.5 \%$ of the differences, with first and second positions accounting for $11.5 \%$ and $2 \%$ of the remaining variable sites, respectively. The type of nucleotide difference was also biased: $79.5 \%$ of the variable sites differed by transitions, $8.5 \%$ by transversions, and $12 \%$ by both. Pairwise sequence differences ranged 
TABLE 3. Nucleotide composition by codon position for Nucella and the outgroup species. Numbers listed are percentages of each nucleotide for first, second, and third positions of codons, as well as the composition for the total region sequenced.

\begin{tabular}{|c|c|c|c|c|c|c|c|c|c|c|c|c|c|c|c|c|}
\hline \multirow{2}{*}{$\begin{array}{l}\text { Nucleotide } \rightarrow \\
\text { Taxon } \downarrow\end{array}$} & \multicolumn{4}{|c|}{$\mathrm{T}$} & \multicolumn{4}{|c|}{$\mathrm{C}$} & \multicolumn{4}{|c|}{ A } & \multicolumn{4}{|c|}{ G } \\
\hline & 1 & 2 & 3 & $T$ & 1 & 2 & 3 & $T$ & 1 & 2 & 3 & $\mathrm{~T}$ & 1 & 2 & 3 & $T$ \\
\hline$P$. columellaris & 32.6 & 42.7 & 44.6 & 40.0 & 16.7 & 22.2 & 13.3 & 17.4 & 21.8 & 20.5 & 32.5 & 24.9 & 28.9 & 14.6 & 09.6 & 17.7 \\
\hline N. freycineti & 28.9 & 41.8 & 47.9 & 39.6 & 20.9 & 22.2 & 12.1 & 18.4 & 21.3 & 20.5 & 37.1 & 26.3 & 28.9 & 15.5 & 02.9 & 15.7 \\
\hline N. lapillus & 30.1 & 41.8 & 52.1 & 41.4 & 19.7 & 21.8 & 07.1 & 16.2 & 20.9 & 20.5 & 35.8 & 25.8 & 29.3 & 15.9 & 05.0 & 16.7 \\
\hline N. lamellosa & 28.9 & 41.8 & 51.7 & 40.8 & 20.9 & 22.2 & 08.7 & 17.3 & 21.3 & 20.1 & 35.0 & 25.5 & 28.9 & 15.9 & 04.6 & 16.4 \\
\hline Average Nucella & 29.4 & 41.7 & 49.1 & 40.1 & 20.4 & 22.2 & 10.9 & 17.8 & 21.0 & 20.4 & 34.2 & 25.2 & 29.3 & 15.6 & 05.9 & 16.9 \\
\hline
\end{tabular}

from $0.0 \%$ to $1.8 \%$ within currently recognized species and from $0.83 \%$ to $12.3 \%$ between species of Nucella (Table 4 ). Nucella species differed by $21.3 \%$ on average from the outgroup species.

The single most parsimonious tree obtained from the analysis of the POLY data set, using an 8:1 weighting of transversions relative to transitions, is shown in Figure 2 . The same data set weighted so that transversions alone were informative also yielded a single most parsimonious tree with an identical topology. Equal weighting of transitions and transversions resulted in two equally parsimonious trees, one of which was topologically identical to Figure 2 and one that differed in the shifting of $N$. lapillus to the $N$. lamellosa branch.

Decay analyses were performed by constructing strict consensus trees of all trees less than or equal to one step longer than the single most parsimonious tree, then two steps longer, etc., until an iteration was reached in which all clades except the eastern and western $N$. lima and the northern and southern $N$. emarginata had collapsed, at 1154 steps (Fig. 2). This analysis was carried out with $8: 1$ weighting, so that eight steps can represent eight transitions or one transversion.

The INDIV data set, which included all 17 haplotypes, yielded a most parsimonious tree topology identical to Figure 2 under all three weighting schemes. The increased resolution of the INDIV data set relative to the POLY data set with equal weighting is an example of the advantage of breaking polymorphic terminal taxa into monomorphic component parts (Nixon and Davis 1991; Maddison and Maddison 1992). Each of the currently recognized species was represented by three haplotypes, except $N$. canaliculata and $N$. emarginata-S, which had two haplotypes, and $N$. emarginata-N, which had one haplotype. Analyses of all $324\left(3^{4} \times 2^{2} \times 1\right)$ possible single-haplotype-per-species combinations for the seven currently recognized species yielded a tree topology identical to Figure 2. The trees varied in length from 1093 to 1117 steps.

The Fitch-Margoliash trees generated from the maximumlikelihood distance matrices were identical in topology to the maximum parsimony tree shown in Figure 2 for all six possible combinations of transition-transversion ratios and categories of substitution rates described above.

\section{Rates of mtDNA Evolution}

Because nucleotides at first and second codon positions varied little among the Nucella sequences, we focused on transitions and transversions at third positions of codons for rate calibrations. Transversions have been found to accumulate most uniformly in the cytochrome $b$ gene of mammals (Irwin et al. 1991). The evolutionary dynamics of first and second codon positions will be dealt with in the broader context of cytochrome b evolution within the caenogastropods (Collins et al. 1992 unpubl.). Absolute time calibration points are based on the fossil occurrences in the Appendix.

Third position transitional differences accrue quite rapidly and begin to approach saturation in the range of five to 10 million yr (Fig. 3a). These differences accumulated at roughly $3-4 \%$ per million yr over the zero- to five-million-yr timescale. The average number of transitional differences peaked sometime after 20 million $\mathrm{yr}$ and then declined in the most

TABLE 4. Pairwise number of sequence differences for selected individuals, all sites, all changes (below diagonal), and mean distances (above diagonal, adjusted for missing data).

\begin{tabular}{|c|c|c|c|c|c|c|c|c|c|c|c|}
\hline & 1 & 2 & 3 & 4 & 5 & 6 & 7 & 8 & 9 & 10 & 11 \\
\hline 1 lima-E & - & 0.018 & 0.110 & 0.110 & 0.110 & 0.123 & 0.120 & 0.118 & 0.116 & 0.123 & 0.120 \\
\hline 2 lima-W & 13 & - & 0.110 & 0.108 & 0.108 & 0.113 & 0.117 & 0.113 & 0.117 & 0.123 & 0.123 \\
\hline 3 freycineti & 79 & 79 & - & 0.007 & 0.010 & 0.078 & 0.088 & 0.087 & 0.091 & 0.099 & 0.094 \\
\hline 4 freycineti & 79 & 77 & 5 & - & 0.006 & 0.077 & 0.085 & 0.084 & 0.092 & 0.103 & 0.101 \\
\hline 5 freycineti & 79 & 77 & 7 & 4 & - & 0.071 & 0.085 & 0.083 & 0.088 & 0.103 & 0.101 \\
\hline 6 lapillus & 88 & 81 & 56 & 55 & 51 & - & 0.089 & 0.086 & 0.098 & 0.112 & 0.106 \\
\hline 7 lamellosa & 86 & 84 & 63 & 61 & 61 & 64 & - & 0.008 & 0.098 & 0.112 & 0.106 \\
\hline 8 lamellosa & 84 & 80 & 62 & 60 & 59 & 61 & 6 & - & 0.083 & 0.094 & 0.091 \\
\hline 9 canaliculata & 83 & 84 & 65 & 66 & 63 & 70 & 62 & 59 & - & 0.092 & 0.090 \\
\hline 10 emarginata-S & 88 & 88 & 71 & 74 & 74 & 80 & 68 & 67 & 66 & - & 0.008 \\
\hline 11 emarginata-N & 86 & 88 & 67 & 72 & 72 & 76 & 66 & 65 & 64 & 6 & - \\
\hline
\end{tabular}




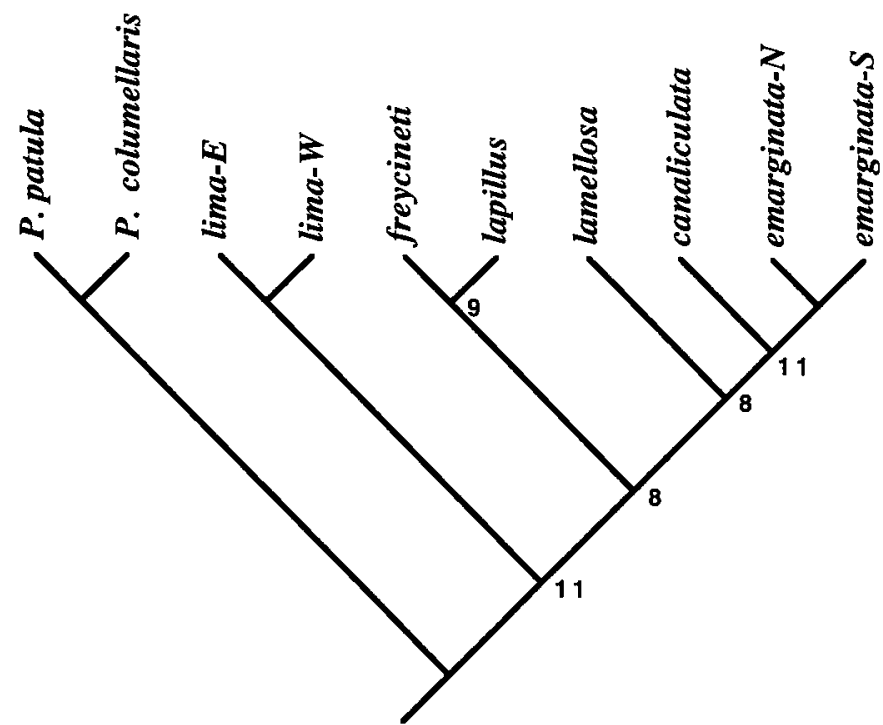

FIG. 2. Single most parsimonious tree obtained for the nucleotide sequence data under a variety of weighting schemes and data structures using maximum parsimony and topology of maximum-likelihood distance tree. With 8:1 weighting of transversions relative to transitions, the most parsimonious tree is 1143 steps. The numerals adjacent to nodes are the decay indices, that is, the minimum number of steps (with 8:1 weighting) beyond the most parsimonious tree at which a node is not found in all trees of equal or lesser length. Nodes without decay indices were supported in all trees within 20 steps of the most parsimonious tree.

ancient comparisons. Mammals exhibit a similar pattern, which appears to result from the accumulation of transversions, which obscures the record of transitions (Brown et al. 1982; Aquadro et al. 1984; Irwin et al. 1991). Third position transversions accumulated more slowly and more uniformly than transitions (Fig. 3b), with an average rate of about one transversion per million yr over the time scale of these comparisons for the 239 third positions of cytochrome $b$ sequenced $(0.42 \%$ per million $\mathrm{yr})$. A similar value, $0.5 \%$ per million yr, was reported for cytochrome $b$ over a comparable time scale for placental mammals (Irwin et al. 1991).

The overall pattern of sequence divergence (Fig. 3c) is typical of animal mitochondrial DNAs, with a steep early rate of divergence that gradually approaches an asymptote with increasing age (Brown et al. 1979). A similar pattern is obtained whether pairwise distances or patristic distances are used (Fig. 3c). The difference between the patristic distance and the pairwise distance becomes progressively greater as

FIG. 3. Relationship between sequence divergence and time for (a) third position transitions; (b) third position transversions; and (c) all nucleotide sequence differences. The $y$-axis is the number of nucleotide differences, the $\mathrm{x}$-axis is time. $=$ individual pairwise phenetic comparisons, $\Delta=$ the average of all pairwise phenetic comparisons at a given time, $\boldsymbol{\square}=$ pairwise patristic distances, $\square$ $=$ the average of all pairwise patristic distances at a given time interval. Patristic distances were generated by reconstructing average branch lengths in MacClade 3.0 and then summing these branch lengths between taxa. Regressions are time against averaged values. See text for further discussion. Fossil occurrences on which these calibrations are based are listed in the Appendix. The

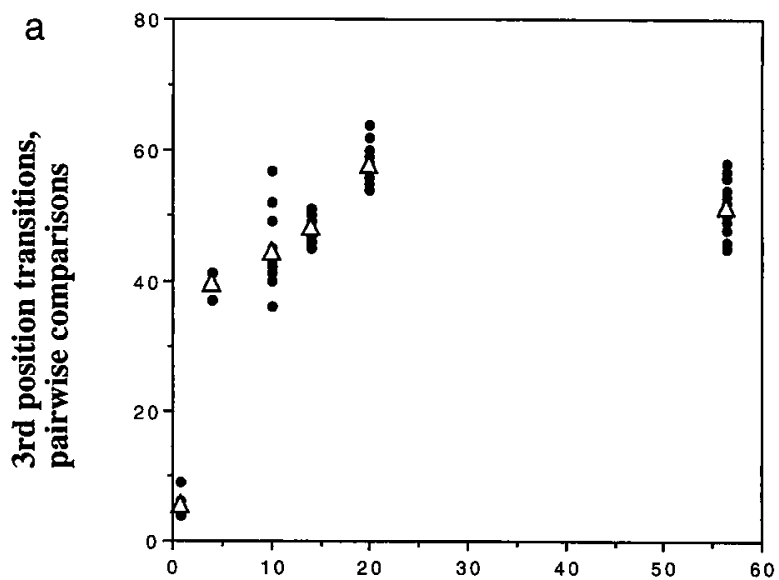

Time (million years)

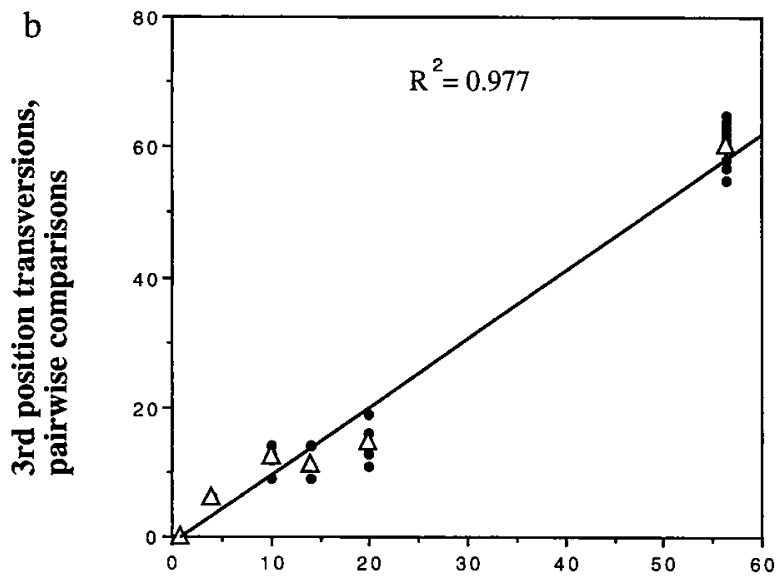

Time (million years)

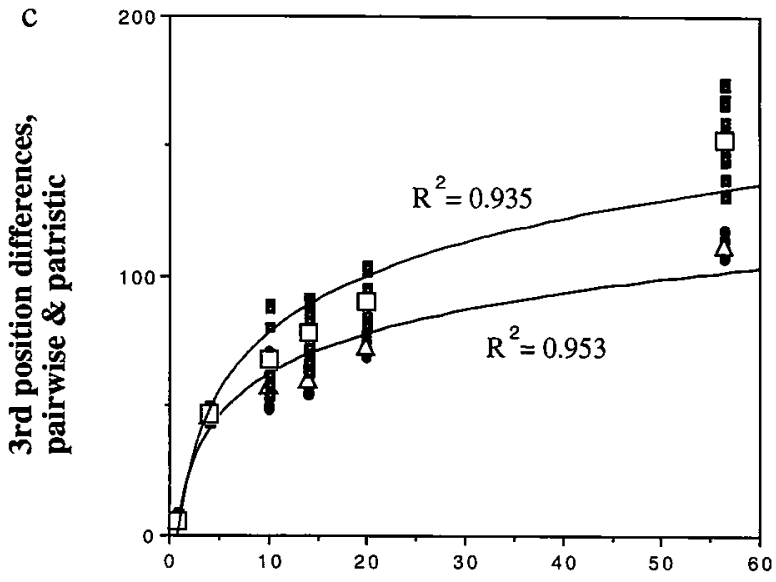

Time (million years)

minimum time of divergence for each node on the most parsimonious tree is estimated as the first occurrence of a fossil representing either of the lineages that descend from that node. The minimum divergence time of the Thaidine lineage leading to Plicopurpura and the Ocenebrine lineage leading to Nucella (55 M.Y.B.P., basal Eocene) is from Kool (1989). The divergences between the eastern and western forms of $N$. lima and northern and southern forms of $N$. emarginata are assumed to have taken place sometime during severe Pleistocene glaciations. The midpoint of the Pleistocene $(8$ $\times 10^{5} \mathrm{yr} \mathrm{bp}$ ) is used as the calibration point for these divergences. 


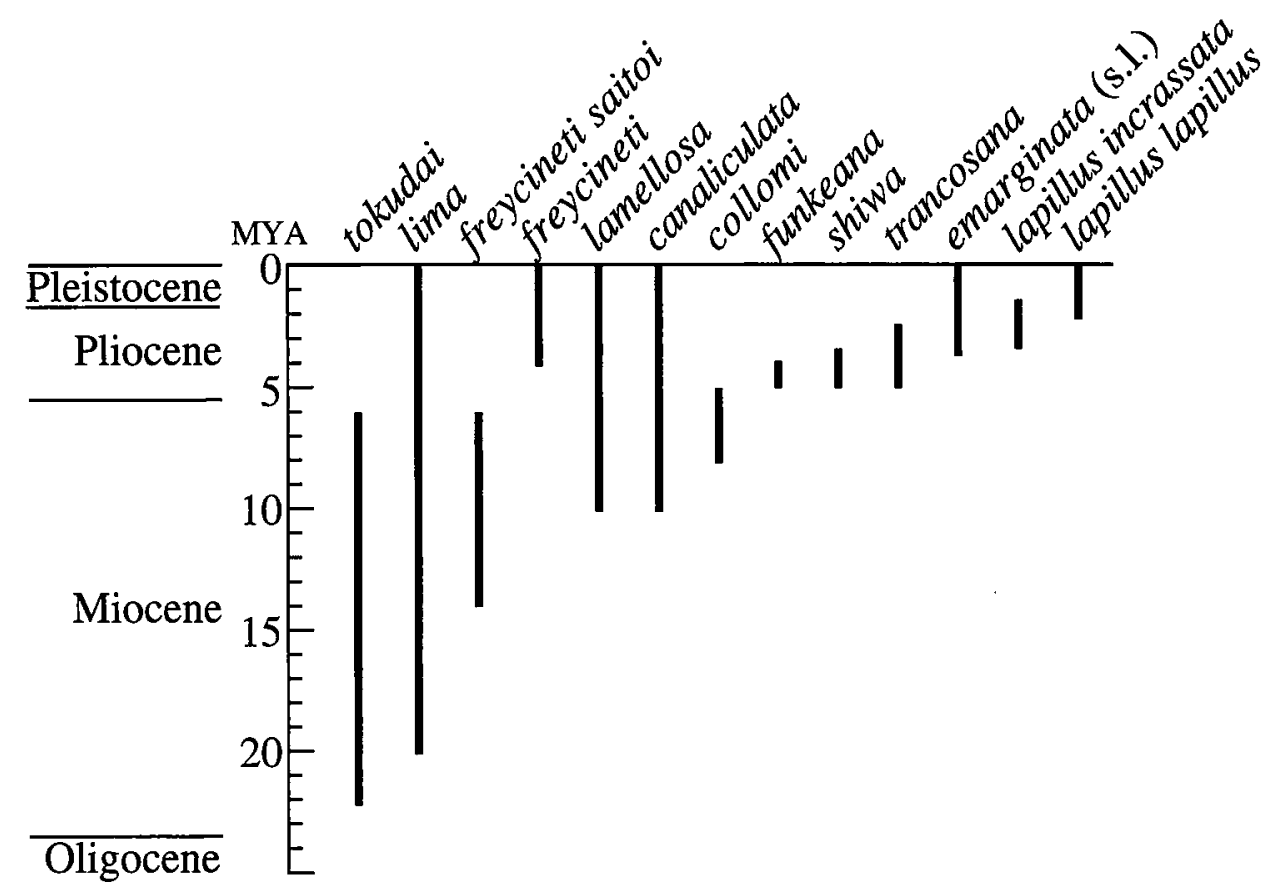

FIG. 4. Stratigraphic ranges of living and extinct species of Nucella. Vertical bars represent the stratigraphic range of each species. Living species are those whose vertical bar intersects the 0 M.Y.B.P. line.

the age of the divergence (and the number of intervening nodes on the cladogram) increases. This is to be expected, as patristic distances for unordered multistate characters cannot be less than, but may be more than, pairwise distances.

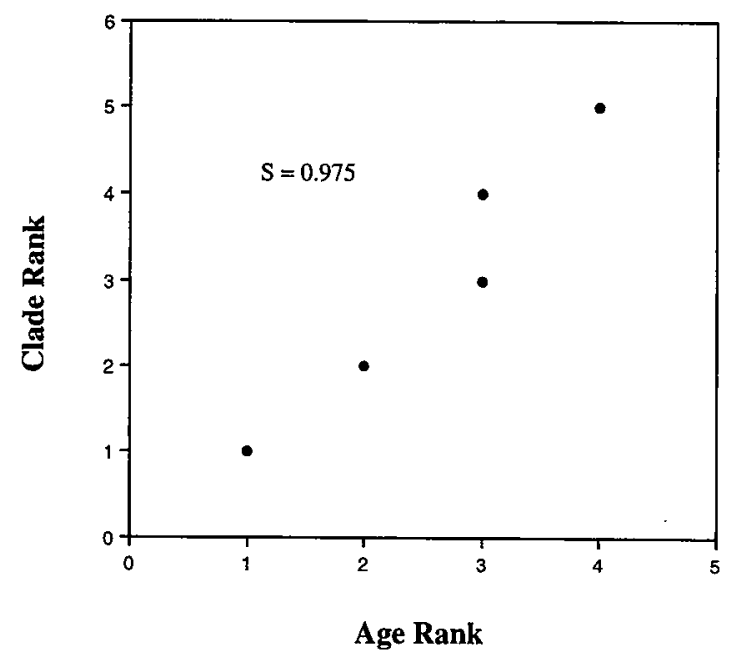

FIG. 5. Relationship between clade rank and age rank for the $\mathrm{Nu}$ cella phylogeny depicted in Figure 2. Clade rank is the order of branching from the base of the cladogram. Age rank is the ranking of species from earliest to latest first occurrence in the fossil record. The phylogeny is reduced to the pectinate components to avoid the difficulty of redundant clade ranks (Norell and Novacek 1992). Clade ranks are $N$. lima, $1 ; N$. freycineti-lapillus, $2 ; N$. lamellosa, $3 ; N$. canaliculata, $4 ; N$. emarginata-S and $-\mathrm{N}, 5$. Age ranks determined from data in Appendix: $N$. lima, $1 ; N$. freycineti-lapillus, 2; $N$. lamellosa, $3 ; N$. canaliculata, $3 ; N$. emarginata-S and $-\mathrm{N}, 4$. Spearman rank coefficient (S) is used to measure the fit between age and clade rank, following the suggestion of Norell and Novacek (1992).
In addition, the number of opportunities for discovering homoplasy (resulting in greater branch lengths) typically increases with an increase in the number of intervening nodes (Sanderson 1990).

\section{Fossil Record}

The known fossil record of Nucella is generally consistent with the branching order of the phylogeny depicted. Basal species appear earlier in the fossil record than more recently derived species (compare Fig. 2 with Fig. 4; see the Appendix for details of the fossil record). In addition, using the methods outlined by Norell and Novacek (1992), age rank (order of appearance of species in the fossil record) was highly correlated with clade rank (branching sequence from the base of the cladogram, for the pectinate components of the tree), indicating that the fossil record of Nucella is consistent with the molecular phylogeny derived here (Fig. 5).

\section{Ecological, Reproductive, and Morphological Attributes of Living Nucella}

Ecological characteristics also varied among species of $\mathrm{Nu}$ cella in a pattern largely consistent with the molecular phylogeny (Table 2). The four more basal species ( $N$. lima, $N$. freycineti, $N$. lapillus, and $N$. lamellosa) all occur commonly in subtidal habitats as well as in quiet water environments, whereas the three more derived species ( $N$. canaliculata, $N$. emarginata-N, and $N$. emarginata-S) occur there only rarely. The two most derived species ( $N$. emarginata-N, $N$. emarginata-S) are also species whose vertical range extends high on the shore, although the sole North Atlantic species (N. lapillus) and the geographically widespread N. lima extend nearly as high. Only the three most basal species $(N$. 
lima, $N$. freycineti, and $N$. lapillus) and one of the most derived species $(N$. emarginata-S) include gastropods in their diet more than $5 \%$ of the time. Finally, all Nucella species produce egg capsules from which juvenile snails emerge (Strathmann 1987), and all except $N$. lamellosa and members of the $N$. freycineti clade provision these egg capsules with nurse eggs (unfertilized eggs consumed by developing embryos).

Shell traits varied substantially among species of Nucella (Table 2). The two most derived species ( $N$. emarginata-N, $N$. emarginata-S) exhibited the smallest average and maximum adult sizes, whereas $N$. lamellosa exhibited the largest average and maximum adult sizes. Well-developed varices (bladelike axial sculpture) occur in only three species $(N$. freycineti, $N$. lapillus [rarely], and $N$. lamellosa), and in all three their expression varies dramatically among habitats. The four most basal species exhibit seven to 10 major spiral ribs on the body whorl, but in the more derived species these have either increased ( $N$. canaliculata) or decreased $(N$. emarginata-N, N. emarginata-S) in number. Conspicuous apertural teeth, which are expressed most consistently in adults (Crothers 1985), occur only in $N$. lapillus and $N$. lamellosa. Unfortunately, information on chromosome numbers was only available for four species (Table 2). Three have $N=35$ chromosomes. Nucella lapillus not only has a smaller number of chromosomes, but is also polymorphic in parts of its range $(N=13$ to 18$)$.

\section{DISCUSSION}

\section{Molecular Evolution and Phylogeny of Nucella}

Weighting.-In mitochondrial DNA sequence comparisons an excess of transitions relative to transversions is commonly observed, both among genes within the same taxa (Brown et al. 1982; Hixson and Brown 1986), and among taxonomic groups (Brown 1985; Moritz et al. 1987; Irwin et al. 1991; Simon 1991). A similar transition excess was observed in the cytochrome $b$ sequence of Nucella. Overall, transitions outnumbered transversions by approximately $4: 1$ to $9: 1$, depending on whether sites having both transitions and transversions were included. As expected, this bias was even more pronounced among closely related terminal taxa, with values of 12:1 for the E and W forms of $N$. lima to $7: 0$ for the N and $\mathrm{S}$ forms of $N$. emarginata and 8:0 between the haplotypes of $N$. freycineti.

For the phylogenetic analyses reported here, we chose an intermediate value of $8: 1$ as a conservative estimate, although the higher values from comparisons among the most closely related taxa are probably closer to the actual values (Brown et al. 1982). For Nucella, the same tree (Fig. 2) was obtained over the range of possible transition-transversion ratios, although the choice of weights often affects tree topology (e.g., Dixon and Hillis 1993).

Decay Analysis.-Decay analysis estimates the level of support for a given clade by determining the maximum number of steps beyond the single most parsimonious tree at or below which that clade is found in all trees (Fig. 2). For our data, the strongest support is for the basal position of the $N$. lima clade within the ingroup, and for the $N$. canaliculata$N$. emarginata northern and southern clade. The weakest sup- port is for the position of $N$. lamellosa and the sister status of $N$. freycineti and $N$. lapillus. We are currently collecting more sequence data from these species as well as from several additional outgroup species to test further the phylogeny presented here. The single most parsimonious tree in Figure 2 is the current best estimate of relationships within Nucella.

Intraspecific Molecular Variation in Nucella.-Although intraspecific polymorphism (both ancestral and in extant populations) among recently diverged taxa may confound phylogenetic studies based on single specimens per taxon (Neigel and Avise 1986; Smouse et al. 1991), the intraspecific variation uncovered in Nucella had no effect on our tree topology. The analysis of all combinations of single haplotypes per species was potentially biased in favor of finding an effect, since we treated the eastern and western forms of $\mathrm{N}$. lima as one species, but in each case we obtained the same tree topology, regardless of the haplotypes chosen to represent a species. At the sequence level we can compare both the kinds and amounts of differences within and between species. Where intraspecific polymorphism is restricted to one kind of change, such as transitions, it should not affect tree topologies supported by, and weighted with respect to, other types of changes, such as transversions.

The cryptic species status of the northern and southern forms of $N$. emarginata is supported by reproductive, morphological, and genetic (allozyme) evidence (Palmer et al. 1990). The sequence divergence between the $N$. emarginata- $\mathrm{N}$ and $N$. emarginata-S individuals sampled in this study $(0.83 \%)$ was the smallest of the between-species comparisons and was unique in being composed entirely of transitional differences. This level and type of sequence divergence was found within single localities of some of the other species of Nucella (e.g., $N$. lamellosa; Table 4). Between-species divergence values approximately equal to within-locality levels of intraspecific polymorphism suggest that this speciation event occurred very recently relative to rates of mitochondrial DNA evolution.

The sequence divergence between the eastern and western forms of $N$. lima $(1.8 \%)$ was more than twice that observed between the northern and southern forms of $N$. emarginata. This hints at the possibility of cryptic species within $N$. lima. An alternative is that these forms represent a deep phylogeographic break within a single species (Avise et al. 1987). More extensive sampling is in progress to verify the geographic pattern of sequence variation and to look for possible correlated morphological variation.

Finally, the distribution of the three haplotypes of $N$. freycineti suggests some geographic patterning. All four individuals from Usujiri are a single haplotype that is approximately $1 \%$ divergent from four of the five individuals sampled from Tsukuskikoi. The last individual from Tsukuskikoi has a unique haplotype, intermediate in distance from the other two haplotypes; it is $0.55 \%$ divergent from the Usujiri haplotype and $0.7 \%$ divergent from the common Tsukuskikoi haplotype. More sampling is needed, but the presence of an intermediate haplotype indicates that we are probably sampling continuous variation along the range of a species with limited gene flow, the type III pattern of Avise et al. (1987).

Calibrating Rates of Molecular Evolution in Marine Gastropods.-The sister species used as outgroups in this study, 
$P$. patula and $P$. columellaris, occur in the Caribbean and eastern Pacific respectively, and are considered to be geminate, a species pair isolated by the Pliocene emergence of the central American Isthmus about 3.5 million yr before present (M.Y.B.P.) (Coates et al. 1992). This independent calibration yields rates of $7.2 \%$ per million yr for third position transitions and $2.4 \%$ per million yr for third position transversions between the Plicopurpura geminates, values considerably higher than those found among Nucella species when calibrated against their fossil record.

Several explanations for this apparent discrepancy are possible. Perhaps the simplest is that the tropical geminate snails are evolving more rapidly than Nucella. If we assume, for the moment, that rates are similar between Nucella and the tropical geminates, the implication is that either the fossil record of Nucella has been misinterpreted, or the geminates were isolated prior to 3.5 M.Y.B.P. The concordance of rate estimates for third position transversions between Nucella and the placental mammals (Irwin et al. 1991) over a similar time scale, suggests that the former explanation is unlikely. Moreover, recent studies of Caribbean Neogene molluscan and foraminiferal assemblages indicate that environmental changes and divergence of populations may have significantly preceded the final emergence of the Central American Isthmus (Jackson et al. 1993; Collins 1993) and molecular work on alpeheid shrimp geminates also hints that some geminates may have been isolated before 3.5 M.Y.B.P. (Knowlton et al. 1993).

If we apply the rate calibration based on the fossil record of Nucella to the average snail geminate divergence, a Middle Miocene isolation is indicated. Clearly, more data are needed to distinguish among these possibilities.

\section{Biogeographic History and Speciation of Nucella}

The combination of molecular and paleontological data, as well as the summary of morphological, life history, and ecological data, allow us to infer the evolutionary history of Nucella. The genus apparently originated during the Early Miocene in the warm-temperate Pacific (see also Amano et al. 1993). By the early Late Miocene, three species ( $N$. lima, $N$. canaliculata, and $N$. lamellosa) living today in cold waters had arisen, so the evolution of cold-water species can be traced back at least to this interval. Expansion of the genus into the Atlantic basin began during the Pliocene. In the following discussion we treat three aspects of the evolution of Nucella in detail: the directionality and timing of the transArctic interchange, parallels between the inferred biogeographic history of Nucella and other North Pacific genera, and evidence that climatic cycling has been important in the diversification of Nucella.

Direction and Timing of the Trans-Arctic Interchange.The phylogeny of Nucella, in which the North Atlantic species $N$. lapillus is nested within the clade of North Pacific Nucella species, confirms the inference from the fossil record that the direction of the interoceanic movement in this genus was from the Pacific to the Atlantic. A possible path for this migration is also indicated. Trans-Arctic migrations via the Canadian Archipelago are usually assumed to have been the probable route of dispersal from the Pacific to the Atlantic during the Pliocene (e.g., Hopkins 1967; Reid 1990b). Nevertheless, the western Pacific sister taxa to the North Atlantic Nucella, the occurrence of Nucella on the Asian Arctic island of Novaya Zemlya (Cooke 1915), and the older fossil record of Nucella in the eastern Atlantic relative to the western Atlantic all suggest that a trans-Eurasian route is at least as likely an alternative for Nucella, and perhaps for other species, as a trans-Canadian dispersal.

Paleontological evidence places the initiation of the transArctic interchange in the Early Pliocene (5.2-3.4 M.Y.B.P., Hopkins 1967; Vermeij 1989a,b, 1991). This is based primarily on the sudden appearance of large numbers of molluscs and other marine benthos of North Pacific affinities in Pliocene fossil beds of the North Atlantic region. If our calibration presented in Figure $3 \mathrm{~b}$ is accepted as a rough approximation, the invasion of the Atlantic by Nucella at 7-8 M.Y.B.P. occurred a little earlier than most estimates of the initiation of the trans-Arctic interchange. Similar dates were obtained when the $N$. freycineti- $N$. lapillus divergence time was removed from the calibration. These inferred divergence times should be regarded as provisional, as they are subject to a number of possible sources of error including fossil misidentification, erroneous estimates of divergence time from fossils, uneven temporal sampling (gap between 20 and 55 million yr), and the possibility of underestimation of molecular distances because of multiple substitutions at a site. A conservative conclusion is that the molecular evidence is consistent with an early participation of Nucella in the transArctic interchange during Late Miocene or Early Pliocene time. The occurrence of Nucella in Late Pliocene deposits of Europe is also consistent with an early participation in the trans-Arctic interchange.

Several other molecular studies also suggest the trans-Arctic interchange may have begun earlier than previously believed. First, allozyme comparisons of two separate invasions of the North Atlantic by the rocky intertidal snail Littorina (Zaslavskaya et al. 1992) indicated an entry between 3.454.05 M.Y.B.P. Second, three different studies of ray-finned fishes thought to have participated in-the trans-Arctic interchange gave estimates of 3.1, 5.1, and 7.9 M.Y.B.P. (Grant et al. 1984; Grant 1986; Grant and Ståhl 1988). Unfortunately, calibrations of $D$ with time vary by almost a factor of four between these studies (a $D$-value of one accumulates in $5 \times 10^{6} \mathrm{yr}$ for snails, but requires $19 \times 10^{6}$ years for rayfinned fishes) tempering somewhat our confidence in the similarity of these values. Other studies indicating significant divergence between Atlantic and Pacific populations include a DNA-DNA hybridization comparison between samples of the seaweed Cladophora albida, in which an estimated sequence divergence equal to that commonly seen between genera of angiosperms was found (Bot et al. 1989), and an allozyme comparison of Atlantic and Pacific Mytilus trossulus in which allele frequency differences at most polymorphic loci were reported (McDonald and Koehn 1988).

In contrast, other comparisons between Atlantic and Pacific populations of taxa indicate low levels of genetic differentiation, implying more recent interchange. Studies of variation in mtDNA restriction endonuclease sites and fragments for Strongylocentrotus droebachiensis (Vawter and Brown 1986; Palumbi and Wilson 1990) and in mtDNA sequence 
comparisons for Strongylocentrotus pallidus (Palumbi and Kessing 1991) revealed remarkable homogeneity of Atlantic and Pacific populations of these species. Allozyme frequencies of Atlantic and Pacific populations is the Greenland Halibut differed only slightly $(D=0.013$, Fairbairn 1981; Grant 1987). Many other examples of low Atlantic-Pacific molecular divergence estimates (Graves et al. 1984; Wilson and Waples 1984; Smith 1986; Bonhomme et al. 1987; Bowen et al. 1989; Graves and Dizon 1989) are possibly the result of continuing gene flow within these species through southern oceans (Palumbi and Kessing 1991) or recent introduction resulting from human commerce (McDonald and Koehn 1988; Meehan et al. 1989).

When viewed collectively, these studies of Atlantic-Pacific differences suggest a bimodal distribution of divergence times. Species have either been isolated since early in the trans-Arctic interchange, or appear to have undergone genetic exchange very recently. The reasons for this apparent bimodality are unclear, but may relate to the sensitivity of these species to extinction and reinvasion during periods of climatic fluctuation (Palumbi and Kessing 1991) or to their relative dispersal ability through cold Northern seas.

Biogeographic Parallels between Nucella and Other Gastropods. - The biogeographic history of Nucella exhibits at least two striking parallels with that of another genus of rocky-shore gastropods, Littorina. First, the linking of the North Atlantic $N$. lapillus to the western Pacific $N$. freycineti parallels the case in Littorina, where at least two independent invasions have occurred from primarily western Pacific lineages to the Atlantic (Reid 1990a,b). This congruence is all the more striking because the mode of larval dispersal in Nucella and the littorinid subgenus Neritrema (by benthic larvae or adults) is different from that of the paraphyletic subgenus Littorina (by planktonic larvae). Second, species with more restricted vertical ranges on the shore appear to be of more recent origin in both Nucella (canaliculata, emarginata- $\mathrm{N}$ and emarginata-S) and in Pacific and Atlantic representatives of the littorinid subgenus Neritrema (Reid 1990a; Vermeij 1992b). Hence in both taxa we see a trend from ecological generalist to ecological specialist.

From another perspective, however, the radiation of $\mathrm{Nu}$ cella appears to contrast with the pattern found in Littorina and in the buccinid genus Neptunea. In both of these latter genera, the oldest and least derived species are thought to have occurred in warm-temperate conditions, whereas more derived and geologically younger species are distributed in cooler shores in the cold-temperate and polar zones (Golikov and Tzvetkova 1972; Reid 1990b). This pattern does not appear to hold for Nucella. Although the oldest species of $\mathrm{Nu}$ cella ( $N$. tokudai) was apparently a warm-temperate species, other geologically old species ( $N$. lima, $N$. freycineti saitoi) are generally cold-temperate species. Furthermore, the warmtemperate $N$. emarginata-S appears to be the most derived and geologically youngest Pacific species of Nucella.

Climatic Vicariance.-The diversification of Nucella in the North Pacific coincides with the beginning of pronounced climatic fluctuations in the Miocene. Cenozoic climatic changes have often been invoked to explain patterns of distribution and speciation in molluscs of the North Pacific (Golikov and Tzvetskova 1972; Valentine and Jablonski 1983;
Valentine 1984; Vermeij 1989b; Reid 1990a,b). The general model presented is one in which fluctuating climatic conditions induce alternating contraction and expansion of species ranges on east-west or north-south trending coastlines, occasionally producing isolated subpopulations that found new species. During cooler intervals, for example, northern populations may become sequestered in pockets of warmer water as surrounding populations of a southern species become locally extinct. Aspects of intraspecific variation, phylogeny, species distribution, and the fossil record of Nucella are compatible with a model of speciation by climatic vicariance.

The boundaries of molluscan biogeographic provinces along the Pacific coast of North America have shifted in response to changing climate (Valentine 1961; Addicott 1966). Ranges of Nucella species were affected by these climatic shifts (e.g., Addicott 1966, 1969), indicating that opportunities existed for isolation of populations of Nucella species during climatic fluctuations. The northern and southern forms of $N$. emarginata and eastern and western forms of N. lima may be the most recent products of a process that has been occurring for much of the Neogene in North Pacific Nucella. The low levels of mtDNA sequence divergence between the northern and southern forms of $N$. emarginata imply that this event probably occurred during severe late Pleistocene climatic cycles.

Patterns of mtDNA sequence variation in $N$. lima discussed above suggest a possible case of east-west isolation by extinction of more northerly intermediate populations. Nucella lima currently ranges continuously from northern Japan through the Kurile, Commander, and Aleutian Islands to the North America continent. During cooler Pleistocene intervals, however, glaciers covered the Alaskan peninsula and large portions of the Aleutian Islands (Hopkins 1967). These Pleistocene glaciers would have effectively bifurcated the range of $N$. lima into more southerly populations in the eastern and western Pacific. These populations would have come into secondary contact as they reclaimed the lost intervening habitat with the retreat of the glaciers during interglacial periods. Whether the current populations of eastern and western $N$. lima are coalescing or have produced new species has not been determined. In general, the results of these cyclical isolation events will depend on a variety of factors, such as the length of time of isolation and population genetic histories during the glacial phase.

\section{Character Evolution within Nucella}

Phylogenetic analyses among taxa above the level of species lose important information about rates of speciation, rates or directions in which particular traits may evolve, correlations between phenotypes and environments that may suggest adaptation, and the phylogenetic origins of new characters (Brooks and McLennan 1991). Thus phylogenetic analyses of intrageneric and intraspecific variation can yield significant insights into rates, correlates, and potential causes of speciation (Avise 1994). The genus Nucella offers an unusual opportunity for such an analysis, because so much is already known about nearly all the extant species. Unfortunately, this analysis is also constrained by the limited number of taxa. Although extensive, prior studies of Nucella have 
generally proceeded within an ahistorical framework because phylogenetic analyses have been thwarted by highly variable morphology (Kincaid 1964; Palmer et al. 1990). The molecular phylogeny offered here allows us to examine evolutionary trends within this well-studied, cosmopolitan genus.

Ecological and Life-History Traits.-An outstanding question in studies of the speciation process is whether founders of new clades are more or less ecologically specialized than the descendants to which they give rise (Mayr 1963). In other words, are ecological generalists more likely to give rise to specialized species that exploit a subset of habitats more effectively, or are ecological specialists more likely to evolve novel attributes that promote subsequent adaptive radiation, including the origin of more generalized species? Similarly, in light of the frequent evolutionary trend towards increased body size observed in fossil invertebrates (Newell 1949), is such a trend apparent within Nucella?

Phylogenetic variation in three ecological traits suggest an evolutionary trend towards increased ecological specialization in Nucella (Fig. 6). First, gastropods have effectively disappeared from the diet in the more derived, northeastern Pacific species ( $N$. lamellosa, N. canaliculata, and $N$. emarginata-N; trait 1, Fig. 6). Their reappearance in the diet of $N$. emarginata-S is clearly a reversion toward the primitive state. Second, nonmytilid bivalves have also disappeared from the diet in this clade (trait 2, Fig. 6). Why gastropods and nonmytilid bivalves are effectively absent from the diet of these three species remains a mystery (Palmer 1988). Third, the most derived, northeastern Pacific species ( $N$. canaliculata, $N$. emarginata-N, and $N$. emarginata-S) are found in a narrower range of habitats. Unlike their inferred ancestors, they are rare or absent in subtidal or very quiet water environments (trait 3, Fig. 6 and Table 2, respectively). Thus diet and habitat breadth became progressively more circumscribed in the northeastern Pacific species. The expansion of the diet in one of the most recently derived eastern Pacific species ( $N$. emarginata-S), though, reveals that such changes are not unidirectional.

The two life-history traits examined exhibited a correlated pattern. First, average adult size and range of adult size (as measured by shell length) increased independently in two lineages ( $N$. freycineti and $N$. lamellosa) and decreased in a third (the $N$. emarginata clade) (Table 2; trait 5, Fig. 6); thus, it appears to be rather labile evolutionarily and no long-term trends are evident. Second, the loss of nurse eggs in $N$. lamellosa and within the freycineti clade are clearly derived states (trait 4, Fig. 6). Nurse eggs are widespread among muricacean gastropods, where they are more commonly associated with direct development than with planktonic larvae (Spight 1976). They also have an ecologically significant impact upon size at hatching: the more nurse eggs, the larger the hatchling size (Rivest 1981). Significantly, the independent loss of nurse eggs occurred in the two clades that also exhibited independent increases in body size ( $N$. freycinet $i$ and $N$. lamellosa), suggesting that increases in adult size are correlated with a novel reproductive pattern that decreases hatchling size ( $P=0.02$, binomial test).

Morphological and Chromosomal Traits._-Vermeij (1987) argues that much morphological evolution in marine invertebrates can be viewed as the result of an "arms race" be- tween predators and prey. Since we know a modest amount about the functional significance of shell traits in gastropods in general (Vermeij 1993b), and about the benefits and costs of shell traits in Nucella in particular (Palmer 1981, 1985, 1992; Crothers 1985), the Nucella phylogeny allows us to ask how evolutionarily labile morphological traits are. For example, are traits that reduce vulnerability to shell-breaking predators ever lost evolutionarily? In addition, for shell traits we can also confirm inferences of ancestral state and patterns of evolution against the fossil record.

Both varices and apertural teeth reduce the vulnerability of shells to peeling predators (Vermeij 1978). However, based on their distribution in extant species of Nucella, both appear quite labile evolutionarily. The common development of conspicuous varices by $N$. freycineti and $N$. lamellosa represent independently derived states (trait 6, Fig. 6), even though varices are widespread among Northern Hemisphere muricacean gastropods (Abbott 1974). Similarly, well-developed apertural teeth arose independently in both $N$. lapillus and $N$. lamellosa (trait 7, Fig. 6). Neither of these traits, however, exhibits a consistent trend to be more well developed in more recently derived species. This result is not surprising. Shelldamaging predators as well as the incidence of repair of shell injuries are greatly reduced in cool-temperate as compared to warm-temperate areas, as evidence for both Nucella and Littorina strongly indicates (Vermeij 1992a). The loss of shell defenses in cool-temperate descendant species of Nucella relative to warm-temperate ancestors is consistent with this difference. Moreover, the phenotypic induction of shell defenses in Nucella in the presence of predatory crabs (Appleton and Palmer 1988; Palmer 1990) strongly underscores the evolutionary lability of predation-related shell traits in this genus.

For the most part, the fossil record confirms the inferred ancestral form and lability of Nucella shell traits. The oldest known species, the Early Miocene $N$. tokudai (as $N$. packi in Addicott 1970), was of intermediate size (to $25 \mathrm{~mm}$ shell length), and lacked well-developed varices and well-developed apertural teeth. Although prominent apertural teeth persist in only two modern species, $N$. lapillus and $N$. lamellosa (Table 2, Fig. 6), they were well developed in the latest Miocene $N$. collomi, and the Late Pliocene $N$. trancosana (Addicott 1969), which may be a close relative of $N$. emarginata. Thus, in spite of their defensive roles, varices and apertural teeth have been lost and regained one or more times over the evolutionary history of Nucella, hence an evolutionary trend toward species with more well-defended shells since the Miocene does not seem evident.

The role that chromosome variation plays in speciation is a source of ongoing controversy (Sites 1995). The reduced number of chromosomes in $N$. lapillus is derived from an ancestral state of $N \geq 30$, when the $N u$ cella data are combined with those of other muricids as well as most neogastropods (numbers vary from $N=30-35$ [Nishikawa 1962; Ahmed and Sparks 1970], character tracing not shown). Reductions in chromosome number seem to occur more commonly than increases in other taxa as well (White 1978). In addition to having fewer chromosomes, $N$. lapillus exhibits a latitudinal cline in chromosome number, with $N=13$ in northern populations and $N=18$ in southern populations. In regions of 

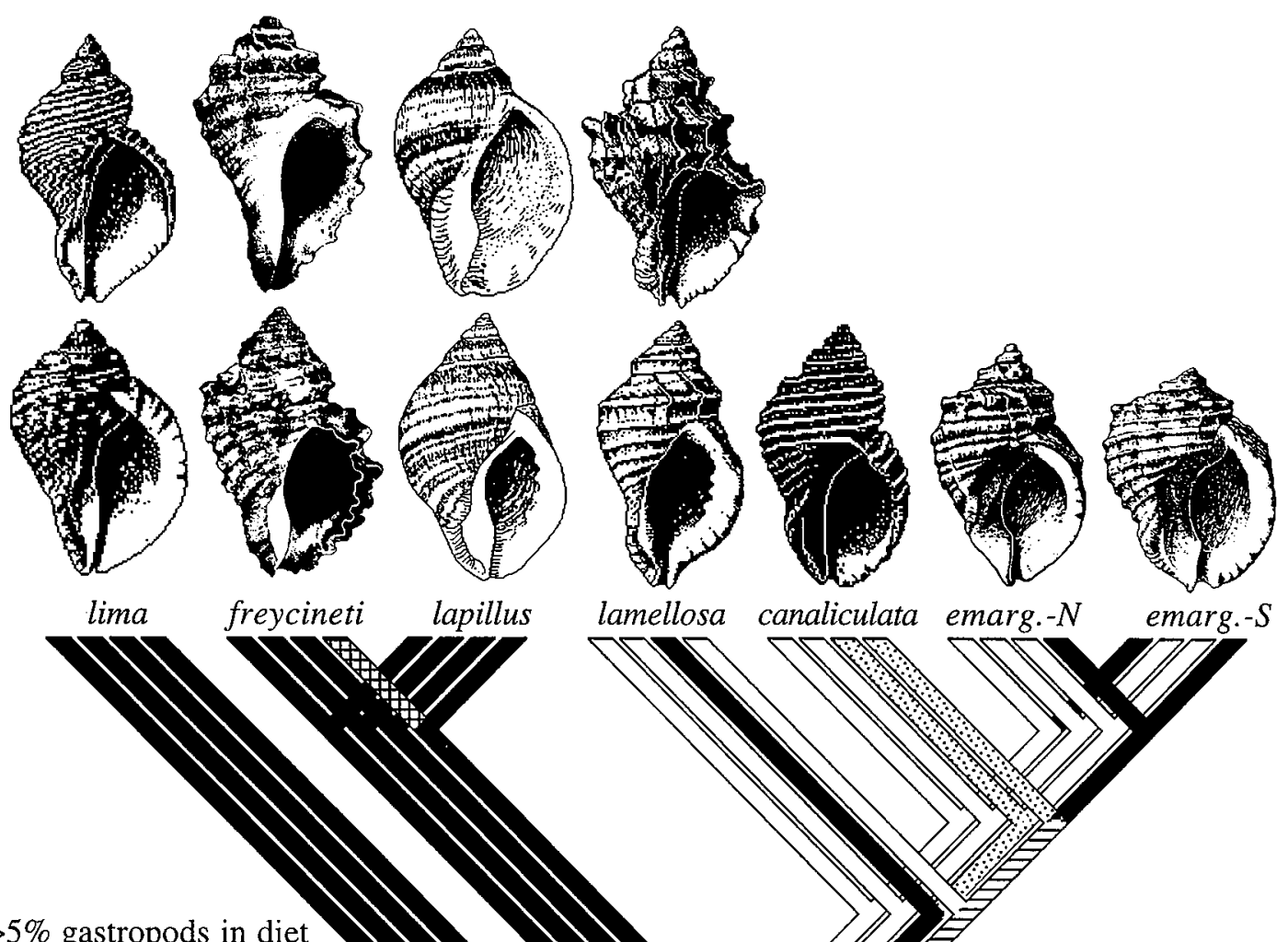

1) $>5 \%$ gastropods in diet

$\square$ no $\square$ yes

2) non-mytilid bivalves in diet

$\square$ no $\square$ yes

3) subtidal populations*

$\square$ no $\quad \square$ rare $\square$ common

4) nurse eggs*

$\square$ no $\mathrm{O}$ few many polym.

lamellosa canaliculata emarg. $N$

emarg. $-S$
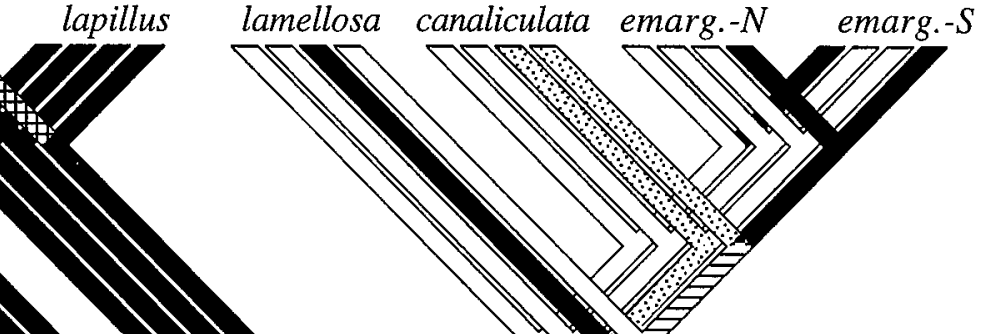

MM

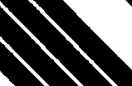


overlap, along the south coast of England and the north coast of France (Staiger 1954; Bantock and Cockayne 1975), clear evidence exists for a Robertsonian polymorphism, a rather common form of polymorphism in hybridizing species (White 1978). Curiously, this latitudinal cline is the reverse of that expected if southern populations were derived from northern ones, which in turn were derived from the ancestral state. Hence either the southern populations experienced a reversion towards the neogastropod norm, or the northern populations are the more derived, perhaps because they arose from a southern stock having $N=18$ chromosomes during the range expansion following Pleistocene glaciations.

\section{CONCLUSIONS}

In this study we have attempted to integrate molecular, morphological, ecological, and paleontological data to understand the evolutionary history of speciation within $\mathrm{Nu}$ cella. These data have given us a more complete and accurate view of the history of this genus than would have been possible if only one of these approaches had been followed. The congruence of inferences from these approaches is a powerful affirmation of the results of each.

The molecular phylogeny derived here is congruent with the order of appearance of taxa in the fossil record. The phylogeny and geographic distribution of living species confirms the inference from the fossil record of a Pacific to Atlantic directionality and early participation of Nucella in the trans-Arctic Interchange. Phylogenetic, biogeographic, and fossil data indicate that a trans-Eurasian dispersal of species into the Atlantic is a viable alternative to the transCanadian hypothesis. Patterns of intraspecific molecular variation and fossil data on shifting biogeographic provinces confirm that climatic cycles initiated during the later Cenozoic can form effective barriers along north-south and east-west coastlines, creating conditions for geographic speciation. The patterns found in Nucella are paralleled in other North Pacific taxa.

Character state reconstruction of morphological and ecological characters of living species suggest an evolutionary trend toward increasing ecological specialization in Nucella. Finally, earlier fossil taxa tend to show the characters inferred by parsimony to be plesiomorphic, although both the phylogeny, as well as fossil and living species, indicate that shell characters are quite labile.

\section{ACKNOWLEDGMENTS}

We thank S. Goshima, K. Kawai, P. B. Marko, L. West, and $\mathrm{N}$. Wheelwright for sending samples of Nucella for DNA analyses; and N. Golikov, S. Goshima, and K. Kawai for sending shells of western Pacific Nucella species. C. Cunningham, R. DeSalle, R. Grosberg, R. Harrison, S. P. Kool, F. Kraus, P. B. Marko, and D. Reid commented on earlier drafts of the manuscript. This research was funded by National Science Foundation grant BSR-9107306 to WMB and TMC, and NSERC Operating Grant A7245 to ARP.

\section{Literature Cited}

Aвbott, R. T. 1974. American seashells. 2d ed. Van Nostran 1 Reinhold, New York.
ADDICOTT, W. O. 1966. Late Pleistocene marine paleoecology and zoogeography in central California. US Geol. Surv. Prof. Pap. 523-C:1-21.

. 1969. Late Pliocene mollusks from San Francisco Peninsula, California, and their paleogeographic significance. Proc. Calif. Acad. Sci. 38:57-93.

. 1970. Miocene gastropods and biostratigraphy of the Kern River Area. US Geol. Surv. Prof. Pap. 642:1-174.

1976a. Molluscan paleontology of the Lower Miocene Clallam Formation, northwestern Washington. US Geol. Surv. Prof. Pap. 976:1-39.

- 1976b. Neogene molluscan stages of Oregon and Washington. Pp. 95-115 in Neogene Symposium. Society of Economic Paleontology and Mineralogy, Pacific Section, Annual Meeting, San Francisco, CA.

. 1978. Marine paleogeography and paleontology of the Salinas basin during the latest part of the Miocene with notes on macrofossils from near San Lucas, California. Neogene biostratigraphy of selected areas in the California coast ranges. US Geol. Surv. Open-File Rep. 78-446:83-90.

. 1981. Significance of pectinids in Tertiary biochronology of the Pacific Northwest. Geol. Soc. Am. Spec. Pap. 184:17-37.

ADEGOKE, O. S. 1969. Stratigraphy and paleontology of the marine Neogene formations in the Coalinga region. Univ. Calif. Publ. Geol. Sci. 80:1-240.

AhMed, M., ANd A. K. Sparks. 1970. A note on the chromosome number and interrelationships in the marine gastropod genus Thais of the United States Pacific coast. Veliger 12:293-295.

Amano, K., G. J. VeRmeIJ, AND K. NARITA. 1993. Early evolution and distribution of the gastropod genus Nucella, with special reference to Miocene species from Japan. Trans. Proc. Palaeontol. Soc. Japan 171:237-248.

Anderson, S., A. T. Bankier, B. G. Barrell, M. H. L. DE Bruijin, A. R. Coulson, J. Drouin, I. C. Eperon, D. P. Nierlich, B. A. Roe, F. Sanger, P. H. Schrier, A. J. H. Smith, R. Staden, AND I. G. YounG. 1981. Sequence and organization of the human mitochondrial genome. Nature 290:457-465.

Appleton, R. D., AND A. R. Palmer. 1988. Water-borne stimuli released by predatory crabs and damaged prey induce more predator resistant shells in a marine gastropod. Proc. Nat. Acad. Sci. USA 85:4387-4391.

Aquadro, C. F., N. Kaplan, AND K. J. Risko. 1984. An analysis of the dynamics of mammalian mitochondrial DNA sequence evolution. Mol. Biol. Evol. 1:423-434.

ARMENTROUT, J. M. 1981. Correlation and ages of Cenozoic chronostratigraphic units in Oregon and Washington. Geol. Soc. Am. Spec. Pap. 184:137-148.

Armentrout, J. M., K. Chinzei, and Y. B. Gladenkov. 1984. Correlation of North Pacific Neogene molluscan biostratigraphic frameworks. Pp. 245-256 in N. Ikebe and R. Tsuchi, eds. Pacific Neogene datum planes: Contributions to biostratigraphy and chronology. Univ. of Tokyo Press, Tokyo, Japan.

Avise, J. C. 1994. Molecular markers, natural history and evolution. Chapman and Hall, New York.

Avise, J. C., J. Arnold, R. M. Ball, E. Bermingham, T. Lamb, J. E. Neigel, C. A. Reeb, ANd N. C. Saunders. 1987. Intraspecific phylogeography: The mitochondrial DNA bridge between population genetics and systematics. Annu. Rev. Ecol. Syst. 18:489-522.

BanTock, C. R., AND W. C. CoCKayne. 1975. Chromosomal polymorphism in Nucella lapillus. Heredity 34:231-245.

BerRy, R. J., AND J. H. Crothers. 1974. Visible variation in the dog-whelk, Nucella lapillus. J. Zool. (Lond.) 174:123-148.

Bonhomme, F., S. Salvidio, A. LeBeau, and G. Pasteur. 1987. Comparaison génétique des tortes vertes (Chelonia mydas) des Oceans Atlantique, Indien, et Pacifique. Genetica 74:89-94.

BOORE, J. L., AND W. M. BROWN. 1994. Complete DNA sequence of the mitochondrial genome of the black chiton, Katharina tunicata. Genetics 138:423-443.

Bot, P. V. M., R. W. Holton, W. T. Stam, and C. Van DEN Hoek. 1989. Molecular divergence between North Atlantic and IndoWest Pacific Cladophora albida (Cladophorales: Chlorophyta) 
isolates as indicated by DNA-DNA hybridization. Mar. Biol. 102:307-313.

Bowen, B., A. B. Meylan, And J. C. Avise. 1989. An odyssey of the green turtle: Ascension Island revisited. Proc. Nat. Acad. Sci. USA 86:573-576.

BREMER, K. 1988. The limits of amino acid sequence data in angiosperm phylogenetic reconstruction. Evolution 42:795-803.

Brooks, D. R., AND D. A. McLennan. 1991. Phylogeny, behavior, and ecology: A research program in comparative biology. Univ. of Chicago Press, Chicago.

Brown, W. M. 1985. The mitochondrial genome of animals. Pp. 95-130 in R. J. MacIntyre, ed. Molecular evolutionary genetics. Plenum Press, New York.

Brown, W. M., M. George JR., AND A. C. Wilson. 1979. Rapid evolution of animal mitochondrial DNA. Proc. Nat. Acad. Sci. USA 76:1967-1971.

Brown, W. M., E. M. Prager, A. Wang, and A. C. Wilson. 1982. Mitochondrial DNA sequences of primates: Tempo and mode of evolution. J. Mol. Evol. 18:225-239.

CAmbridge, P. G., AND J. A. Kitching. 1982. Shell shape in living and fossil Nucella lapillus (L.) in relation to habitat. J. Conchol. 31:31-38.

Cantatore, P., M. Roberti, G. Rainaldi, M. N. Galadeta, and C. SACCONE. 1989. The complete nucleotide sequence, gene organization and genetic code of the mitochondrial genome of Paracentrotus lividus. J. Biol. Chem. 264:10965-10975.

Chinzei, K. 1961. Molluscan fauna of the Pliocene Sannohe Group of northeast Honshû, Japan. 2. The faunule of the Togawa Formation. J. Fac. Sci. Univ. Tokyo (Sec. II) 13:81-131.

Clary, D. O., and D. R. Wolstenholme. 1985. The mitochondrial DNA molecule of Drosophila yakuba: Nucleotide sequence, gene organization and genetic code. J. Mol. Evol. 22:252-271.

Coates, A. G., J. B. C. Jackson, L. S. Collins, T. M. Cronin, H. J. Dowsetr, L. M. Bybell, P. Jung, And J. A. Obando. 1992. Closure of the Isthmus of Panama: the near-shore marine record of Costa Rica and western Panama. Geol. Soc. Am. Bull. 104: 814-828

Collins, L. S. 1993. Neogene paleoenvironments of the Bocas del Toro Basin, Panama. J. Paleontol. 67:699-710.

Collins, T. M. 1989. Rates of MtDNA evolution in transisthmian geminate species. Ph.D. diss. Yale Univ. New Haven, CT.

Collins, T. M., K. S. Frazer, AND W. M. Brown. 1992. Molecular dynamics of mitochondrial cytochrome $b$ in prosobranch gastropods. P. 211 in F. Guisti and G. Manganelli, eds. Unitas Malacologia, 11th international malacological congress abstracts. Univ. of Siena, Siena, Italy.

Cooke, A. H. 1915. The geographical distribution of Purpura lapillus (L.). Part 1. In Palæ arctic waters. Proc. Malacol. Soc. Lond. 11:192-209.

Crothers, J. H. 1985. Dog-whelks: An introduction to the biology of Nucella lapillus (L.). Field Studies 6:291-360.

DALL, W. H. 1915. Notes on the species of the molluscan subgenus Nucella inhabiting the northwest coast of America and adjacent regions. Proc. US Nat. Mus. 49:557-572.

1920. Pliocene and Pleistocene fossils from the Arctic coast of Alaska and the auriferous beaches of Nome, Norton Sound, Alaska. US Geol. Surv. Prof. Pap. 125-C:23-34.

Dixon, M. T., AND D. M. Hillis. 1993. Ribosomal RNA secondary structure: Compensatory mutations and implications for phylogenetic analysis. Mol. Biol. Evol. 10:256-267.

Donoghue, M. J., R. G. Olmstead, J. F. Smith, and J. D. Palmer. 1992. Phylogenetic relationships of dipsacales based on $r b c \mathbf{L}$ sequences. Ann. Missouri Bot. Gard. 79:333-345.

DoYle, J. J. 1990. Isolation of plant DNA from fresh tissue. Focus 12:13-15.

Durham, D. L., And W. O. Addicott. 1965. Pancho Rico Formation, Salinas Valley, California: A study of stratigraphy and paleontology of Pliocene marine strata in southern Salinas Valley, California. US Geol. Surv. Prof. Pap. 524-A:1-22.

EgoRov, R. V. 1992. Guide to recent molluscs of northern Eurasia. 1. Gastropods of the families Muricidae and Thaididae from the seas of Russia. Ruthenica 2:63-75.

ETHERINGTON, T. J. 1931. Stratigraphy and fauna of the Astoria
Miocene of southwest Washington. Univ. Calif. Publ. Geol. Sci. 20:31-142.

FAIRBAIRN, D. J. 1981. Biochemical genetic analysis of population differentiation in Greenland halibut (Reinhardtius hippoglossoides) from the Northwest Atlantic, Gulf of St. Lawrence, and Bering Sea. Can. J. Fish. Aquat. Sci. 38:669-677.

FelsensteIn, J. 1991. PHYLIP (phylogeny inference package) Vers. 3.4. Distributed by the author. Univ. of Washington, Seattle.

Gibbard, P. L., R. G. West, W. H. Zagwin, R. S. Balson, A. W. Burger, B. M. FunNell, D. H. JefFery, J DEJong, T. VAN KolfSchoten, A. M. Lister, T. Meijer, P. E. P. Norton, R. C. Preece, J. Rose, A. J. Stuart, C. A. Whiteman, And J. A. Zalasiewicz. 1991. Early and Middle Pleistocene correlations in the southern North Sea Basin. Quat. Sci. Rev. 10:23-52.

Gladenkov, Y. B., V. M. Gladikova, A. N. Kafanov, L. V. KoNOVA, L. V. KRISThofovich, V. N. Sinelnikova, AND S. V. PoPOV. 1984. Marine mollusks. Atlas Fauny i Flory Neogenovych Otlozhenii Dal'nego Vostoka: Tochilinskiy Oppornyy Razrez Zapadnoi Kamchatki. Acad. Nauka Geol. Inst. Trudy 385:152250.

GLIBERT, M. 1959. Gasteropodes du Diestien, du Scaldisien, et du Merxémien de la Belgique. Troisième note. Bull. Inst. R. Sci. Nat. Belgique 35:1-27.

1963. Les Muricacea et Buccinacea fossiles du Cenozoïque étranger des collections de l'Institut Royal des Sciences Naturelles de Belgique. Mém. Inst. R. Sci. Nat. Belgique 73:1-179.

Golikov, A. N., AND O. G. Kussakin. 1962. Fauna and ecology of prosobranch gastropods of the littoral of the Kuril Islands. Stud. Far-Eastern Seas USSR 8:248-346.

1978. Shelled gastropod molluscs of the littoral seas of the Soviet Union. Nauka, Leningrad, USSR.

Golikov, A. N., AND N. L. TzvetKova. 1972. The ecological principle of evolutionary reconstruction as illustrated by marine animals. Mar. Biol. 14:1-9.

Grant, U. S., IV, and H. R. Gale. 1931. Catalogue of the marine Pleistocene molluscs of California and adjacent regions. Mem. San Diego Soc. Nat. Hist. 1:1-1036.

Grant, W. S. 1986. Biochemical genetic divergence between Atlantic, Clupea harengus, and Pacific, C. pallasi, herring. Copeia (3):714-719.

1987. Genetic divergence between congeneric Atlantic and Pacific Ocean fishes. Pp. 225-246 in N. Ryman and F. Utter, eds. Population genetics and fisheries management. Univ. of Washington Press, Seattle.

Grant, W. S., AND G. STÅHL. 1988. Evolution of Atlantic and Pacific cod: Loss of genetic variation and gene expression in Pacific cod. Evolution 42:138-146.

Grant, W. S., D. J. Teel, T. Kobayashi, and C. Schmitt. 1984 Biochemical population genetics of Pacific halibut (Hippoglossus stenolepis) and comparison with Atlantic halibut ( $H$. hipploglossus). Can. J. Fish. Aquat. Sci. 41:1083-1088.

Graves, J. E., AND A. E. Dizon. 1989. Mitochondrial DNA sequence similarity of Atlantic and Pacific albacore tuna (Thunnus alalunga). Can. J. Fish. Aquat. Sci. 46:870-873.

Graves, J. E., S. D. Ferris, ANd A. E. Dizon. 1984. Close genetic similarity of Atlantic and Pacific skipjack tuna (Katsuwonus pelamis) demonstrated with restriction endonuclease analysis of mitochondrial DNA. Mar. Biol. 79:315-319.

HABE, T. 1958. Fauna of Akkeshi Bay. XXV. Gastropoda. Publ. Akkeshi Mar. Biol. Sta. 8:1-39.

. 1964. Shells of the western Pacific in color. Vol. 2. Hoikusha Publ. Co., Osaka, Japan.

HABE, T., AND K. ITO. 1971. Shells of the world in colour. Vol. I. The North Pacific. Hoikusha Publ. Co., Osaka, Japan.

Hixson, J. E., AND W. M. Brown. 1986. A comparison of the small ribosomal RNA genes from the mitochondrial DNA of the great apes and humans: Sequence, structure, evolution, and phylogenetic implications. Mol. Biol. Evol. 3:1-18.

HoPKINS, D. M. 1967. The Cenozoic history of Beringia-A synthesis. Pp. 451-484 in D. M. Hopkin, ed. The Bering land bridge. Stanford Univ. Press, Stanford, CA. 
Hughes, R. N. 1986. A functional biology of marine gastropods. Johns Hopkins Univ. Press, Baltimore, MD.

IRwin, D. M., T. D. Kocher, AND A. C. WILson. 1991. Evolution of cytochrome $b$ gene in mammals. J. Mol. Evol. 32:128-144.

JaCkson, J. B. C., P. Jung, A. G. Coates, AND L. S. Collins. 1993. Diversity and extinction of tropical American molluscs and closure of the Isthmus of Panama. Science 260:1624-1626.

JaCobs, H. T., D. J. Elliott, V. B. Math, and A. Farquharson. 1988. Nucleotide sequence and gene organization of sea urchin mitochondrial DNA. J. Mol. Biol. 202:185-217.

KAWAI, K. 1993. Ecological energetics of the dogwhelk Nucella freycineti (Deshayes) populations. Ph.D. diss. Univ. of Hokkaidô, Hokkaidô, Japan.

KILBURN, R., AND E. RipPEY. 1982. Sea shells of southern Africa. Macmillan South Africa, Johannesburg, South Africa.

KINCAID, T. 1964. Notes on Thais (Nucella) lima (Gmelin), a marine gastropod inhabiting areas in the North Pacific Ocean. Calliostoma Co. Seattle, WA.

Knowlton, N., L. A. Weigt, L. A. Solózano, D. E. K. Mills, AND E. BERmingham. 1993. Concordant divergence in allozymes, mtDNA, and reproductive compatibility across the Isthmus of Panama. Science 260:1629-1631.

KooL, S. P. 1989. Phylogenetic analysis of the subfamily Thaidinae (Prosobranchia: Neogastropoda: Muricidae). Ph.D. diss., George Washington Univ., Washington, DC.

- 1993a. Phylogenetic analysis of the Rapaninae (Neogastropoda: Muricidae). Malacologia 35:155-259.

- 1993b. The systematic position of the genus Nucella (Prosobranchia: Muricidae: Ocenebrinae). Nautilus 107:43-57.

Kreitman, M., A. Berry, L. Landweber, ANd M. TAylor. 1989. The Hacker's guide to PCR. Polymerase Chain Letter 1:1-13.

MacNeil, F. S., J. B. Mertie Jr., And H. A. Pilsbry. 1943. Marine invertebrate faunas of the buried beaches near Nome, Alaska. J. Paleontol. 17:69-96.

Maddison, W. P., AND D. R. Maddison. 1992. MacClade: Analysis of phylogeny and character evolution. Vers. 3.0. Sinauer, Sunderland, MA.

MARINCOVICH, L., JR. 1983. Molluscan paleontology, paleoecology, and North Pacific correlations of the Miocene Tachilni formation, Alaska Peninsula, Alaska. Bull. Am. Paleontol. 84:59155.

MAYR, E. 1963. Animal species and evolution. Harvard Univ. Press, Cambridge, MA.

McDonald, J. H., and R. K. KoEhn. 1988. The mussels Mytilus galloprovincialis and $M$. trossulus on the Pacific coast of North America. Mar. Biol. 99:111-118.

Meehan, B. W., J. T. Carlton, and R. Wenne. 1989. Genetic affinities of the bivalve Macoma balthica from the Pacific coast of North America: Evidence for recent introduction and historical distribution. Mar. Biol. 102:235-241.

MENGE, B. A. 1976. Organization of the New England rocky intertidal community: Role of predation, competition and environmental heterogeneity. Ecol. Monogr. 46:355-393.

Moritz, C., T. E. Dowling, AND W. M. Brown. 1987. Evolution of animal mitochondrial DNA: Relevance for population biology and systematics. Annu. Rev. Ecol. Syst. 18:269-292.

NeIgel, J. E., AND J. C. Avise. 1986. Phylogenetic relationships of mitochondrial DNA under various demographic models of speciation. Pp. 515-534 in S. Karlin and E. Nevo, eds. Evolutionary processes and theory. Academic Press, Orlando, FL.

Newell, N. D. 1949. Phyletic size increase, an important trend illustrated by fossil invertebrates. Evolution 3:103-124.

NishIKAWA, S. 1962. A comparative study of chromosomes in marine gastropods with some remarks on cytotaxonomy and phylogeny. J. Shimonoseki Coll. Fish. 11:149-186.

Nixon, K. C., AND J. I. Davis. 1991. Polymorphic taxa, missing values and cladistic analysis. Cladistics 7:233-241.

Norell, M. A., AND M. J. NovaceK. 1992. Congruence between superpositional and phylogenetic patterns: Comparing cladistic patterns with fossil records. Cladistics 8:319-337.

PALMER, A. R. 1980. A comparative and experimental study of feeding and growth in thaidid gastropods. Ph.D. diss., Univ. of Washington, Seattle.
1981. Do carbonate skeletons limit the rate of body growth? Nature 292:150-152.

1985. Adaptive value of shell variation in Thais (or $\mathrm{Nu}$ cella) lamellosa: Effect of thick shells on vulnerability to and preference by crabs. Veliger 27:349-356.

. 1988. Feeding biology of Ocenebra lurida (Prosobranchia: Muricacea): Diet, predator-prey size relations, and attack behavior. Veliger 31:192-203.

1990. Effect of crab effluent and scent of damaged conspecifics on feeding, growth, and shell morphology of the Atlantic dogwhelk Nucella lapillus (L.). Hydrobiologia 193:155182.

. 1992. Calcification in marine molluscs: How costly is it? Proc. Nat. Acad. Sci. USA 89:1379-1382.

Palmer, A. R., S. D. Gayron, AND D. S. Woodruff. 1990. Reproductive, morphological, and genetic evidence for two cryptic species of Northeastern Pacific Nucella. Veliger 33:325-338.

Palumbi, S. R., AND B. D. Kessing. 1991. Population biology of the trans-Arctic interchange: mtDNA sequence similarity between Pacific and Atlantic sea urchins. Evolution 45:1790-1805.

Palumbi, S. R., AND A. C. Wilson. 1990. Mitochondrial DNA diversity in the sea urchins Strongylocentrotus purpuratus and $S$. droebachiensis. Evolution 44:403-415.

REID, D. G. 1990a. A cladistic phylogeny of the genus Littorina (Gastropoda): Implications for evolution of reproductive strategies and for classification. Hydrobiologia 193:1-19.

1990b. Trans-Arctic migration and speciation induced by climatic change: The biogeography of Littorina (Mollusca: Gastropoda). Bull. Mar. Sci. 47:35-49.

RICHARDS, H. G. 1962. Studies of the marine Pleistocene. Part II. The marine Pleistocene mollusks of eastern North America. Trans. Am. Phil. Soc. 52 42-141.

Rivest, B. R. 1981. Nurse egg consumption and the uptake of albumen in the embryonic nutrition of marine snails. Ph.D. diss., Univ. of Washington, Seattle.

SANDERson, M. J. 1990. Estimating rates of speciation and evolution: A bias due to homoplasy. Cladistics 6:387-391.

Simon, C. 1991. Molecular systematics at the species boundary: Exploiting conserved and variable regions of the mitochondrial genome of animals via direct sequencing from amplified DNA. Pp. 34-71 in G. M. Hewitt, A. W. B. Johnston, and J. P. W. Young, eds. Molecular techniques in taxonomy. NATO ASI Ser. $\mathrm{H}$, Cell Biology, 57. Springer-Verlag, Berlin.

SITES, J. W., JR. 1995. Chromosomal speciation. Evolution 49:218222.

SMITH, P. J. 1986. Genetic similarity between samples of the orange roughy Hoplosteus atlanticus from the Tasman Sea, South-west Pacific Ocean and North-east Atlantic ocean. Mar. Biol. 91:173180.

Smouse, P. E., T. E. Dowling, J. A. Tworek, W. R. Hoeh, AND W. M. BROWN. 1991. Effects of intraspecific polymorphism on phylogenetic inference: A likelihood analysis of mtDNA restriction site data in cyprinid fishes. Syst. Zool. 40:393-409.

SPIGHT, T. M. 1976. Ecology of hatching size for marine snails. Oecologia 24:283-294.

STAIGER, H. 1954. Der chromosomendimorphismus beim Prosobranchier Purpura lapillus in Beziehung zur ökologie der Art. Chromosoma 6:419-478.

StrathmanN, M. F. 1987. Reproduction and development of marine invertebrates of the northern Pacific coast. Univ. of Washington Press, Seattle.

SwOFFoRD, D. L. 1990. PAUP: Phylogenetic analysis using parsimony. Vers. 3.0q. Distributed by the Illinois Natural History Survey, Champaign.

VALENTINE, J. V., AND D. JABLONSKI. 1983. Speciation in the shallow sea: general patterns and biogeographic controls. Pp. 201226 in R. W. Sims, J. H. Price, and P. E. S. Whalley, eds. Evolution, time and space: The emergence of the biosphere. Academic Press, New York.

VAlentine, J. W. 1961. Paleoeculogic molluscan geography of the Californian Pleistocene. Univ. Calif. Publ. Geol. Sci. 34:309442 .

- 1984. Climate and evolution in the shallow sea. Pp. 265 
277 in P. J. Brenchly, ed. Fossils and climate. John Wiley and Sons, New York.

VAWTER, L., AND W. M. BROWN. 1986. Nuclear and mitochondrial DNA comparisons reveal extreme rate variation in the molecular clock. Science 234:194-196.

VermeIJ, G. J. 1978. Biogeography and adaptation: Patterns of marine life. Harvard Univ. Press, Cambridge, MA.

. 1987. Evolution and escalation. An ecological history of life. Princeton Univ. Press, Princeton, NJ.

1989a. Invasion and extinction: The last three million years of North Sea Pelecypod history. Conserv. Biol. 3:274-281.

. 1989b. Geographical restriction as a guide to the causes of extinction: The case of the cold northern seas during the Neogene. Paleobiology 15:335-356.

1991. Anatomy of an invasion: The trans-Arctic interchange. Paleobiology 17:281-307.

1992a. Repaired breakage and shell thickness in gastropods of the genera Littorina and Nucella in the Aleutian Islands, Alaska. Pp. 135-139 in J. Grahame, P. J. Mill, and D. G. Reid, eds. Proceedings of the third international symposium on littorinid biology. Malacological Society of London, London.

$1992 \mathrm{~b}$. Time of origin and biogeographical history of specialized relationships between northern marine plants and herbivorous molluscs. Evolution 46:657-664.

- 1993a. Spinucella, a new genus of Miocene to Pleistocene muricid gastropods from the eastern Atlantic. Contr. Tert. Quat. Geol. 30:19-27.

1993b. A natural history of shells. Princeton Univ. Press, Princeton, NJ.

VermeiJ, G. J., A. R. Palmer, and D. R. Lindberg. 1990. Range limits and dispersal of mollusks in the Aleutian Islands, Alaska. Veliger 33:346-354.

Weaver, C. E. 1942. Paleontology of the marine Tertiary formations of Oregon and Washington. Univ. Wash. Publ. Geol. 5: $1-790$.

WEST, L. 1986. Interindividual variation in prey selection by the snail Nucella ( = Thais) emarginata. Ecology 67:798-809.

WhITE, M. J. D. 1978. Modes of speciation. Freeman, San Francisco, CA.

WILSON, R. R., AND R. S. WAPLES. 1984. Electrophoretic and biometric variability in the abyssal grenadier Coryphaenoides armatus of the western North Atlantic, eastern South Pacific, and eastern North Pacific oceans. Mar. Biol. 80:227-237.

Zaslavskaya, N. I., S. O. Sergievsky, and A. N. Tatarenkov. 1992. Allozyme similarity of Atlantic and Pacific species of Littorina (Gastropoda: Littorinidae). J. Moll. Stud. 58:377-384.

Corresponding Editor: R. DeSalle

APPENDIX

Geological occurrences, distributions, and characteristics of fossil species of Nucella and dates used for calibration of rates of molecular evolution of Nucella species.

\section{Nucella tokudai}

The earliest recognized species of Nucella is N. tokudai (Yokoyama 1932) (see Amano et al. 1993). This species has pronounced uniform spiral cords and lacks axial ribs, which are character states expected to be primitive (see Evolutionary Trends within Nucella). Addicott (1970) synonymized $N$. carrizoensis (Loel and Corey 1932) $(=N$. tokudai; see Amano et al. 1993) with Thais packi Clark 1918, which was described from the earliest Miocene or latest Oligocene San Ramon Sandstone of California. Amano et al. (1993), however, have shown that T. packi possesses the trace of a labral spine on the edge of the shell's outer lip and belongs in the related genus Acanthinucella.

Nucella tokudai (Yokoyama 1932) $(=N$. packi Clark 1918 of Addicott [1970] not $N$. packi Clark 1918; and $=N$. carrizoensis [Loel and Corey 1932]): Early Miocene Vaqueros Formation and Jewett sandstone in California; early Middle Miocene Chikubetsu and Middle Okada beds in Hokkaidô, Kakert Formation of Kamchatka; Middle Miocene Tem- blor Formation, Sobrante Sandstone and Floras Lake Sandstone USA, Ishiizawa Formation of Hokkaido; Late Miocene Togeshita Formation (upper part) in Hokkaido and Cierbo Sandstone in California (K. Amano et al. unpubl.); earliest occurrence 23-21 M.Y.B.P.

\section{Nucella lima}

The oldest specimens attributed to the living $N$. lima were described by Etherington (1931). Our examination of Etherington's material (Museum of Paleontology, University of California, Berkeley, number 32004) revealed that these shells resemble $N$. lima in overall shape, in the absence of axial sculpture, and in the pattern of spiral sculpture of alternating large and small cords. However, the number of cords on the penultimate whorl and last whorl is less on the fossil shells ( 2 and 16 , respectively) than on shells of living $N$. lima (3 and 18 to 20 , respectively). We therefore regard these Miocene specimens as belonging to the $N$. lima lineage, but a definitive assignment must await the collection of additional material. In any case, the $N$. lima lineage seems to have been present at an early stage in the history of Nucella.

Nucella lima (Gmelin 1791) s. 1.: late early Miocene to early middle Miocene Astoria Formation of southwestern Washington (Etherington 1931; Addicott 1976a,b; Armentrout et al. 1984) to Recent; earliest occurrence 23-17 M.Y.B.P. Calibration date 20 M.Y.B.P.

\section{Nucella freycineti}

The $N$. freycineti lineage is recorded from early Middle Miocene onward. The Miocene forms, which have been assigned to $N$. freycineti saitoi Hatai and Kotaka, 1959 (see Amano et al. 1993) have shells that lack axial ribs and therefore resemble Deshayes's types of the living $N$. freycineti rather than the axially sculptured forms that have been named $N$. heyseana and $N$. elongata. Typical $N$. freycineti is recorded from Pliocene to Recent deposits in Japan (Amano et al. 1993). Dall (1920) named specimens from Pliocene deposits near Nome, Alaska, as $N$. nomiana, but these specimens probably represent $N$. freycineti (MacNeil et al. 1943) since they exhibit seven widely spaced major spiral cords on the body whorl and lack apertural teeth.

Nucella freycineti saitoi Hatai and Kotaka 1959: Middle Miocene Ginzan and Tachikaraushinai Formations (K-AR dated, 13.7 to 13.8 M.Y.B.P.) to late Miocene Togeshita FORMATION (upper part) of Japan and Kamchatka (Amano et al. 1993). Calibration date 14 M.Y.B.P.

Nucella freycineti (Deshayes 1841): Pliocene to Recent of Japan and Kamchatka (K. Amano et al. unpubl.), Pliocene of Nome, Alaska as $N$. nomiana (Dall 1920); earliest occurrence 5.2-3.4 M.Y.B.P. Calibration date 4 M.Y.B.P

\section{Nucella lamellosa}

Fossils identified as $N$. lamellosa by Gladenkov et al. (1984) from the early Late Miocene Etolon Suite of Kamchatka may represent either an unnamed ancestral taxon or a lamellose form of $N$. f. saitoi similar to the living axially ribbed forms of $N$. freycineti. In the living fauna, $N$. lamellosa is confined to the eastern Pacific (Vermeij et al. 1990),

Nucella lamellosa (Gmelin 1791) s. 1.: early late Miocene Graysian and Wishkahan stages of Oregon and Washington, Etolon Formation of Kamchatka, "Jacalitos" stage of California (Grant and Gale 1931; Weaver 1942; Addicott 1976b, 1978; Marincovich 1983) to Recent; earliest occurrence 12-7 M.Y.B.P. Calibration date 10 M.Y.B.P.

\section{Nucella canaliculata}

Nucella canaliculata (Duclos 1832): early late Miocene Graysian and Wishkahan stages of Oregon and Washington (as N. precursor Dall 1909) (Weaver 1942; Addicott 1976b, 1978, 1981; Marincovich 1983) to Recent; earliest occurrence 12-7 M.Y.B.P. Calibration date 10 M.Y.B.P.

\section{Nucella collomi}

Nucella collomi Carson 1926 is a distinctive species from the Late Miocene of California characterized by numerous scaly spiral cords, 
which may be uniform or alternating in strength, and a long siphonal canal.

Nucella collomi (Carson 1791): latest Miocene Pancho Rico Formation of California (Durham and Addicott 1965; Addicott 1978); 85 M.Y.B.P.

\section{Nucella funkeana}

Nucella funkeana (Adegoke 1969): Pliocene Etchegoin stage of California (Adegoke 1969); 5-4 M.Y.B.P.

\section{Nucella shiwa}

Nucella shiwa (Chinzei 1961) (=?N. freycineti): Pliocene Togawa Formation of northern Honshû, Japan (Chinzei, 1961); 5-3.5 M.Y.B.P.

\section{Nucella trancosana}

Nucella trancosana is a low-spired thick-shelled species with strong apertural teeth that extend into the aperture as ribs, a short siphonal canal, and numerous spiral cords (up to 24) on the body whorl.

Nucella trancosana (Arnold 1908): Pliocene Merced Formation of California and Cantil Costero Formation of Baja California (Addicott 1969); 5-2.5 M.Y.B.P.

\section{Nucella emarginata}

The $N$. emarginata clade is the last of the living Nucella to appear in the fossil record of the eastern Pacific and is known from Pliocene time onward.
Nucella emarginata (Deshayes 1839) s. l.: Moclipsian (Pliocene) stage of Oregon and Washington (as N. ostrina [Gould]), Merced Formation of California to Recent (Addicott 1969, 1976b, 1978; Armentrout 1981; Armentrout et al. 1984) to Recent; earliest occurrence 52.5 M.Y.B.P

\section{Nucella lapillus}

Nucella is first recorded in the North Atlantic in deposits of Late Pliocene age. The earliest Atlantic form is $N$. lapillus incrassata (Sowerby 1825). Its high-spired shell resembles that of the northeastern Pacific N. lamellosa, but it lacks the axial sculpture of that species. Typical $N$. lapillus, whose shell is generally lower-spired and more weakly sculptured, appears in the latest Pliocene and in the overlying Early Pleistocene. The western Atlantic population of $N$. lapillus, which is morphologically indistinguishable from that in Europe, is recorded from the Late Pleistocene onward (Richards 1962). Nucella tetragona (Sowerby 1825) was regarded as the earliest Atlantic species of the genus, but this species belongs in another genus Spinucella that neither descended from nor gave rise to Nucella (Vermeij 1993a).

Nucella lapillus incrassata (Sowerby 1825): late Pliocene Red Crag of England and Merxemian stage of Belgium (Glibert 1959, 1963; Gibbard et al. 1991); 3.4-1.8 M.Y.B.P.

Nucella lapillus lapillus (Linnaeus 1758): Early Pleistocene Norwich Crag of England to Recent in Europe, Mediterranean, and Morocco: late Pleistocene (40 M.Y.B.P.) to Recent in eastern North America (Glibert 1959, 1963), (Richards 1962; Cambridge and Kitching 1982). 